\title{
Petrography and Geochemical Characterization of Dolerites from Figuil (Northern Cameroon) and Léré (Southwestern Chad)
}

\author{
Moussa Ngarena Klamadji ${ }^{*}$, Merlin Gountié Dedzo², Rigobert Tchameni ${ }^{3}$, Daouda Dawaï ${ }^{4}$ \\ ${ }^{1}$ Département des Sciences de la Vie et de la Terre, Faculté des Sciences Techniques et de la Technologie, Université de Pala, \\ Pala, Tchad \\ ${ }^{2}$ Department of Life and Earth Sciences, High Teachers' Training College, University of Maroua, Maroua, Cameroon \\ ${ }^{3}$ Department of Earth Sciences, Faculty of Science, University of Ngaoundéré, Ngaoundéré, Cameroon \\ ${ }^{4}$ Department of Earth Sciences, Faculty of Science, University of Maroua, Maroua, Cameroon \\ Email: *klamadjimoussa@yahoo.fr
}

How to cite this paper: Klamadji, M.N., Dedzo, M.G., Tchameni, R. and Dawaï, D. (2020) Petrography and Geochemical Characterization of Dolerites from Figuil (Northern Cameroon) and Léré (Southwestern Chad). International Journal of Geosciences, 11, 459-482.

https://doi.org/10.4236/ijg.2020.117023

Received: April 5, 2020

Accepted: July 13, 2020

Published: July 16, 2020

Copyright () 2020 by author(s) and Scientific Research Publishing Inc. This work is licensed under the Creative Commons Attribution International License (CC BY 4.0)

http://creativecommons.org/licenses/by/4.0/

\section{(c) (i) Open Access}

\begin{abstract}
This work presents the petrographic and geochemical data of the dolerite dykes crosscutting the Pan-African basement of Figuil (North-Cameroon) and Léré (South-West Chad) in order to approach their petrogenesis and their emplacement context. Two groups of dolerites have been highlighted by petrographic and geochemical studies. These groups were discriminated by their $\mathrm{TiO}_{2}, \mathrm{Fe}_{2} \mathrm{O}_{3}, \mathrm{REE}, \mathrm{Ba}, \mathrm{Nb}, \mathrm{Zr}$, La and $\mathrm{Hf}$ contents which are relatively higher in group I; group II, on the other hand, has higher $\mathrm{MgO}, \mathrm{Mg \#}$, Sc, Ni and $\mathrm{Cr}$ contents. The mineralogical assemblage of these dolerites is made up by plagioclases, pyroxenes, olivine, oxides, amphibole, biotite and sometimes pyrite, calcite, apatite, epidote and chlorite. The behaviour of the major and trace elements suggest that studied dolerites have an evolution dominated by fractional crystallization. Most dolerite samples show higher REE concentrations and $(\mathrm{La} / \mathrm{Yb})_{\mathrm{N}}>8.7,(\mathrm{~Tb} / \mathrm{Yb})_{\mathrm{N}}>1.9$ and $\mathrm{Dy} / \mathrm{Yb}>2$ ratios characterizing a garnet-bearing mantle. The difference in incompatible elements between the two groups is explained by the degree of partial melting of the same source which becomes more important over time. Low $(\mathrm{Ce} / \mathrm{Yb})_{\mathrm{N}}$ values $(3.3$ - 11.58) also suggest relatively low partial melting degree of the source. Fractional crystallization process was possibly combined with minor crustal contamination as shown by enrichment of $\mathrm{Th} / \mathrm{Yb}$ from group II to Group I that might be due to turbulent magma emplacement. The chemical compositions of these dolerites are similar to that of continental tholeiites with slightly moderate negative $\mathrm{Nb}-\mathrm{Ta}$ anomalies which are attributed to crustal contamination of magmas. As other dolerites of Cameroon, continental tholeiitic signature of the studied dolerites is evidenced in geotectonic discrimination diagrams with Group II
\end{abstract}


dolerite compositions falling within the field of tholeiitic basalts and group I within the field of alkali basalts.

\section{Keywords}

Doleritic Dykes, Pan-African Basement, Continental Tholeiites, North-Cameroon, South-West of Chad

\section{Introduction}

Mafic dyke swarms provide the most complete record of short-lived, mantlegenerated magmatic events through time and space [1] [2]. The crystallization of basaltic magmas can also occur on the subsurface in the form of sills and dolerite dykes. These intrusions are often formed and located in areas of high orogenic activity (shear and collision zones) and are intrinsically linked to the dynamics of mountain ranges. Intrusive magmatism generally exploits synchronous fracturing systems and may also follow pre-existing reactivated systems with networked organizations [3]. Their study is therefore fundamental for understanding the geological history. In the Pan-African Central African Fold Belt (CAFB), petrographic, geochemical and geochronological data were obtained from several magmatic intrusions (e.g. [4]-[9] amongst others). The Dolerite investigated in the present study is located in the northern domain of CAFB in Cameroon and southwest of Chad. Its preliminary geochemical data of some samples in Cameroon domain of CAFB were presented in Ngounouno et al. [10]. Geochemical studies of the dolerites of Chad have so far not been carried out, as well as comparisons of those of neighboring Cameroon. The aim of this study is to characterize, constraint the petrogenesis and define geotectonic context of the Figuil (Cameroon) and Léré (Chad) dolerites using new major, trace and REE compositions data.

\section{Regional Geological Setting and Geological Background of the Study Area}

The Central African Fold Belt is one of the most important tectonic units of Precambrian central Africa. It has been formed by the collision between three main cratonic blocks: the Congo craton, the West African craton and the Saharan metacraton during the West Gondwana assembly [11] [12]. During this collision, the margins of the cratons were fragmented and remobilized by the metacratonization process. Sub-blocks are delimited by large shear zones and are characterized by metacratonic and non-metacratonic domains [13]. It is an orogenic mega-belt that crosses several territories (Nigeria, Cameroon, Central African Republic, Chad). This Belt has the characteristics of a collision chain [14], with external nappes of regional extension, high-pressure granulite metamorphism, intense migmatization, regional-scale stalls and the presence of molasse deposits [14]. The emplacement of intrusions, which very often outcrop into dykes and sills, is 
considered to be a direct consequence of tectonic events affecting the Pan-African basement [15] [16].

In southwestern Chad Republic and in northern Cameroon (Figure 1), Neoproterozoic magmatic arcs circumscribed by medium to narrow low grade volcanosedimentary schist belts have been defined. These volcanosedimentary sequences include Goueygoudoum greenstone and Zalbi belts in southwest Chad, and the Rey Bouba, Bibemi-Zalbi and Poli greenstone belts in northern Cameroon [17] (Table 1). These sequences were commonly interpreted as pre-tectonic back-arc basins intruded by or associated with the calc-alkaline TTG suite of the Mayo Kebbi Batholiths and Sinassi [15] [18] [19] [20] (Table 1).

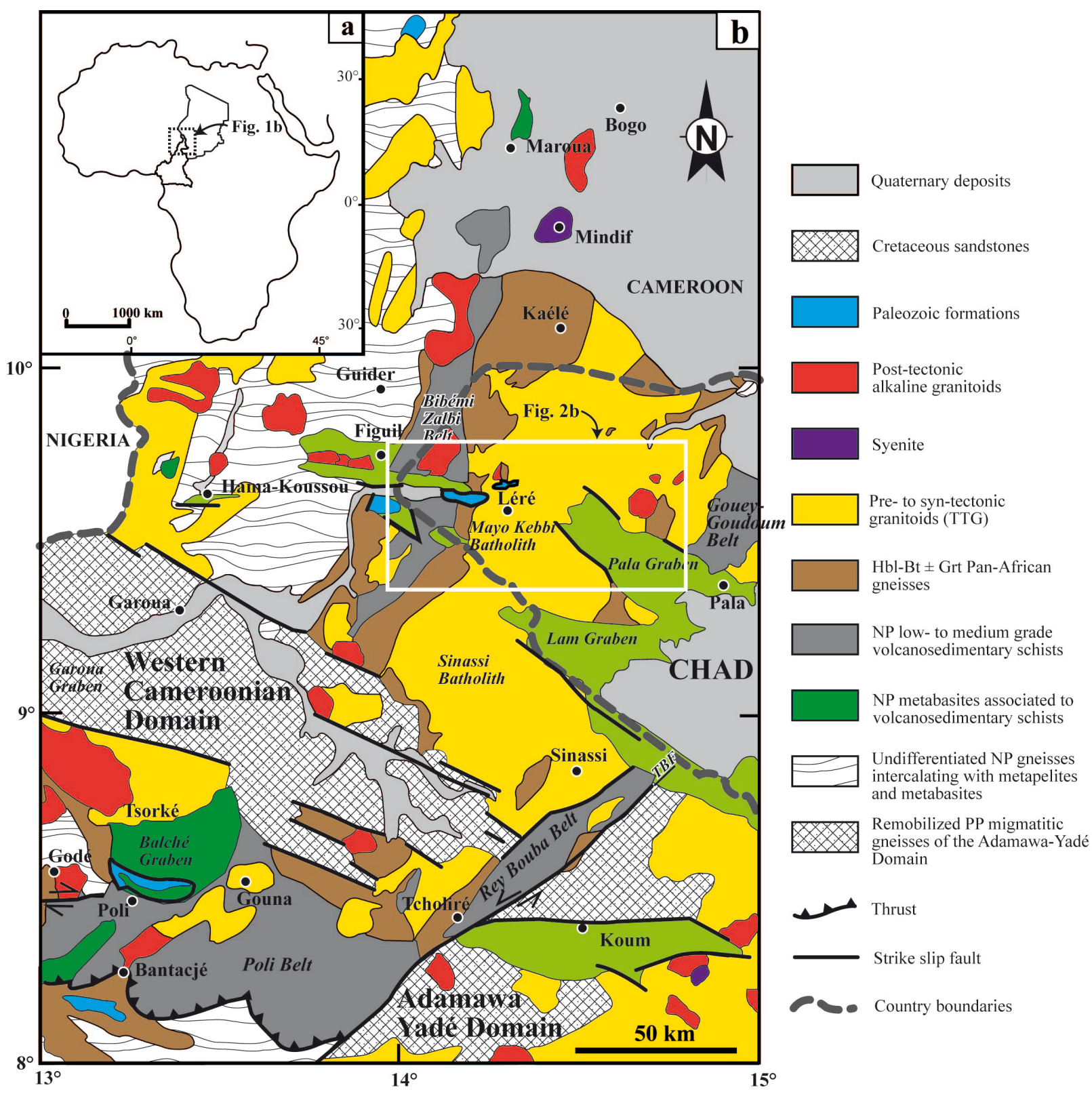

Figure 1. (a) Location of Cameroon and Chad in Africa. (b) Geological map of Northern Cameroon and Southwestern Chad (redraw from Bouyo et al. [17]). TBF: Tcholliré-Banyo Fault; NP: Neoproterozoic; PP: Paleoproterozoic. 
Table 1. Summary table showing the main features and geochronological data for all major belts and batholiths of north Cameroon and southwest Chad at the northern margin of the CAFB (Bouyo Houketchang et al. [53]).

\begin{tabular}{|c|c|c|c|c|}
\hline Country & Volcanosedimentary belts & Major lithologies & Main features & Geochronological data \\
\hline Cameroon & Poli Belt [18] [64] [65] & $\begin{array}{l}\text { Greywacke-type metasediments } \\
\text {-Volcanogenic clastic rocks } \\
\text { (mainly tuff) } \\
\text {-Tholetiitic basalt } \\
\text {-Calc-alkaline rhyolite } \\
\text {-Pre, syn-to post tectonic } \\
\text { granitoids }\end{array}$ & $\begin{array}{l}\text {-Low to high grade } \\
\text {-NE trend of foliation } \\
\text { appears consistent } \\
\text { throughout the } \\
\text { different belts } \\
\text {-Strong sub-vertical } \\
\text { foliation }\end{array}$ & $\begin{array}{l}\text {-Origin of detrital sources: } 920,830 \text {, } \\
\text { 780, } 736 \mathrm{Ma} \\
\text {-Depositional age: } 700-665 \mathrm{Ma} \\
\text {-Age of deformation: } 612 \mathrm{Ma} \\
\text { (Badjouma metadiorite) } \\
\text {-Age of metamorphism: ca } 600 \mathrm{Ma} \\
\text { (High pressure metapelitic granulite) }\end{array}$ \\
\hline \multirow[t]{2}{*}{ Chad } & Rey Bouba Belt [19] & $\begin{array}{l}\text {-Flysch (greywacke and pelite) } \\
\text {-Sandstone, siltstone, black } \\
\text { shale, limestone and dacite } \\
\text {-Conglomerate and } \\
\text { coarse-grained arkose with } \\
\text { pebbles of volcanic rock } \\
\text {-Andesitic and dacitic tuff and brec- } \\
\text { cias } \\
\text {-Pre, syn-to post tectonic } \\
\text { granitoids }\end{array}$ & $\begin{array}{l}\text {-Low to medium grade } \\
\text {-Basin located along a } \\
\text { strike slip fault } \\
\text { (Tcholliré-Banyo Fault) }\end{array}$ & -Depositional age: $750 \mathrm{Ma}$ \\
\hline & Bibémi-Zalbi Belt & & -Low to medium grade & \\
\hline Chad & Goueygoudoum [20] & $\begin{array}{l}\text {-Spilitic rocks } \\
\text {-Black shale and chert } \\
\text {-Sandy and silty claystone } \\
\text {-Basaltic volcanic and } \\
\text { volcanosedimentary rocks } \\
\text {-Pre, syn-to post tectonic } \\
\text { granitoids } \\
\text {-Covered by thick soil and shows } \\
\text { only few bedrock outcrops }\end{array}$ & -Low to medium grade & $\begin{array}{l}\text {-Crystallization: } 700 \mathrm{Ma} \text { (metabasalt), } \\
777 \mathrm{Ma} \text { (epiclastite) }\end{array}$ \\
\hline Country & Batholith (magmatic arc) & Major lithologies & Main features & Geochronological data \\
\hline Cameroon & $\begin{array}{l}\text { Sinassi Batholith } \\
\text { [19] [67] }\end{array}$ & $\begin{array}{l}\text {-Tonalite Trondjemite-Granodiorite } \\
\text { (TTG) }\end{array}$ & -Calc-alkaline suite & $\begin{array}{l}\text {-Crystallization: } 690 \mathrm{Ma} \text { (Doudja } \\
\text { tonalite) } \\
\text {-Age of emplacement: } 677 \mathrm{Ma} \text { (Sinassi } \\
\text { tonalite) } \\
\text {-Age of deformation: } 639 \mathrm{Ma} \text { (Landou } \\
\text { granite) }\end{array}$ \\
\hline Chad & $\begin{array}{l}\text { Mayo Kebbi Batholith } \\
\text { [20] [21] }\end{array}$ & $\begin{array}{l}\text {-Gabbro-diorite metadiorite } \\
\text {-TTG } \\
\text {-Granodiorite-monzodiorite }\end{array}$ & -Calc-alkaline suite & $\begin{array}{l}\text {-Age of emplacement: ca } 740 \mathrm{Ma} \\
\text { (Boloro metadiorite), } 723 \mathrm{Ma} \text { (Boloro } \\
\text { gabbro-diorite), ca } 665 \text { - } 640 \mathrm{Ma} \\
\text { (Matanseng tonalite), } 570 \mathrm{Ma} \text { (Pala } \\
\text { granodiorite) }\end{array}$ \\
\hline
\end{tabular}

The Mayo Kebbi granito-gneissic basement, which extends from Poli in Cameroon to southwestern Chad characterized by foliation oriented N-S to NNE-SSW with NNE-SSW folds was interpreted as the Neoproterozoic formations and emplaced around 740 to $540 \mathrm{Ma}$ (Penaye et al., 2006). It is the result of a successive magmatic arc development since $740 \mathrm{Ma}$ followed by a collision of three different domains (Adamaoua-Yadé, Mayo-Kebbi and Poli), crossed by granitoids, emplaced 
around 737 - $570 \mathrm{Ma}$ [17] [21]. The Léré Basin basement belongs to the large group known as the Mayo Kebbi region. This group represents the NE extension of the Pan-African basement of Poli in Central North Cameroon [21]. It is an assemblage of Phanerozoic sediments covering a Precambrian substratum dominated by intrusive tonalitic batholith in amphibole gneissic complexes [22].

Cretaceous sediments are deposited in two basins (Figure 2) bounded by E-W faults, whose extensional rework in the early Cretaceous controlled the emplacement of veins and sills [23] [24]. The Pan-African basement of Figuil contains five distinct facies, dominated by tonalitic orthogneisses and intersected by peraluminous granite veins. In sum, the Figuil gneissic basement is composed of more or less orthogneissitic magmatic rocks, crosscut by pegmatite veins of magmatic character [25].

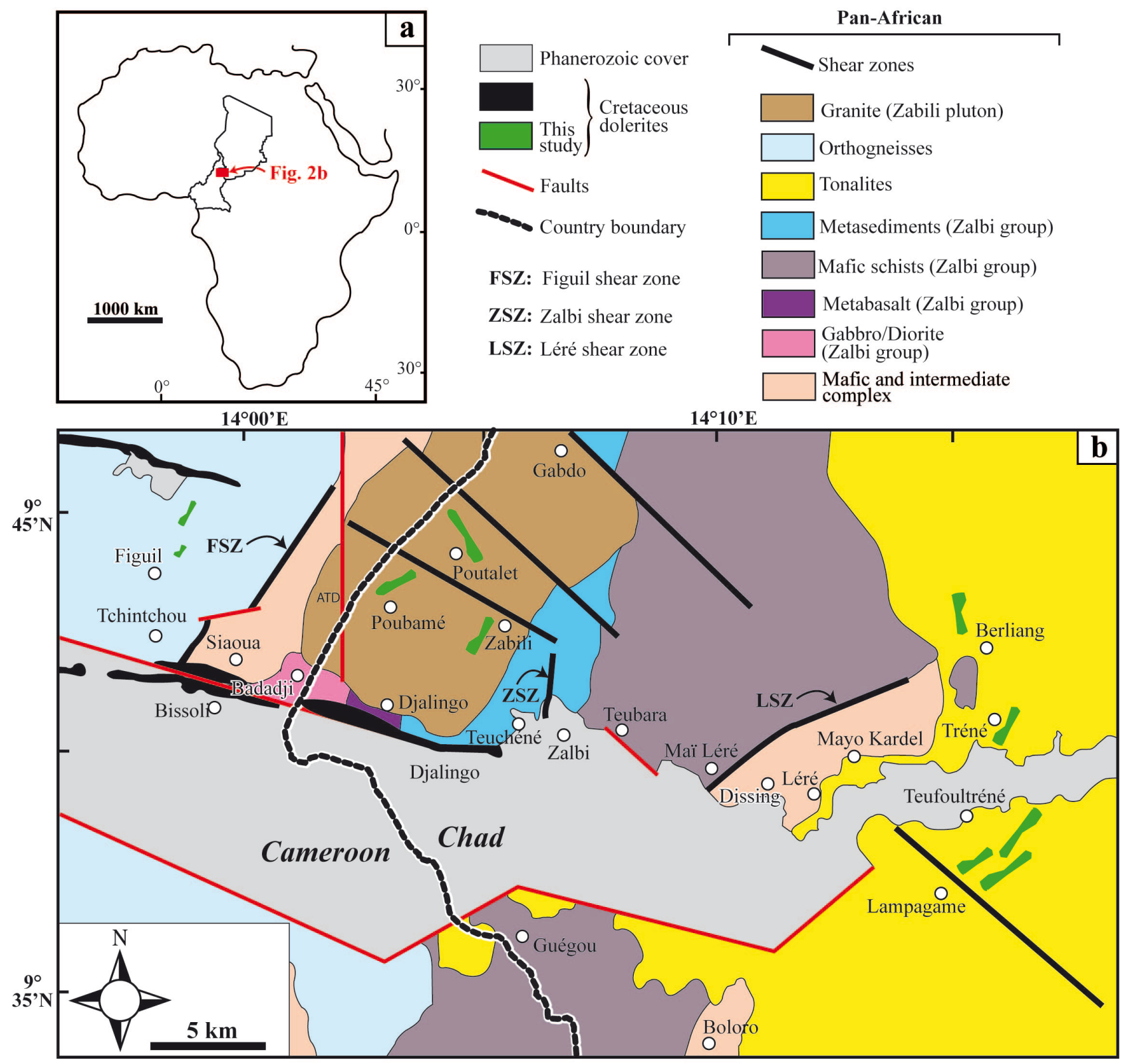

Figure 2. Geological sketch map of Figuil-Léré area (modified from Isseini et al. [25]). 
At Léré, the contacts are identified and characterized between the Zalbi metavolcanosedimentary series and the Mafic and intermediate complex on the one hand, and between the latter and the Léré batholith on the other hand. Chloritoschists with talcist intercalations and rare serpentinites constitute the metavolcanosedimentary series. Gabbros, gabbro-diorites and quartz diorites representing the Mafic and Intermediate Complex outcrop to the east of the Zalbi, Boloro and Léré series. South of Lake Léré, the Guegou tonalite (Figure 2) is a circular intrusion described as a diorite and attributed to the Mafic and Intermediate Complex by Pouclet et al. [20]. The presence of vein-like appendages of Léré's batholith in the Mafic and Intermediate Complex suggests the intrusive character of the former in the latter [25]. As part of the CPAC, the Figuil (northern Cameroon) and Léré (south-western Chad) regions have dolerites outcropping on the Pan-African basement and in sedimentary formations. Rejuvenation of Pan-African faults favored the emplacement of the dykes and sills in the area [23] [24]. Post-rift transpression affected Figuil and Léré basins as part of the Central African Senonian Fold Belt [26] [27]. The dolerites are therefore characterized by an impressive system of dykes emplacement strongly linked to the tectonic events that affected these regions.

The ages of these doleritic intrusions are not exactly well-known. However, similar basalts, microgabbros and dolerites sampled eastwards in Chad, in the same basin, gave $\mathrm{K}-\mathrm{Ar}$ ages between $43 \pm 2$ and $87 \pm 3 \mathrm{Ma}$ [28]. Furthermore, structural field observations show that the dykes are older than the regional Late Eocene compressive event [26] [29].

\section{Sampling and Analytical Methods}

Ten (10) fresh and representative samples from two groups of dolerites were selected for the petrographic and geochemical studies. Each sample was carefully cleaned and then sawn into two parts. Ten rock samples were sent to Bureau Veritas Mineral Laboratories in Vancouver, Canada for geochemical analyzes. The ten others were sent to Key laboratory Coalbeb Methane Resource and Reservoir Training in China, for the preparation of thin sections. Rock powder of each sample $(0.2 \mathrm{~g})$ was added to lithium metaborate/lithium tetraborate flux $(0.90 \mathrm{~g})$, well mixed and fused in a furnace at $1000^{\circ} \mathrm{C}$. The resulting melt was then cooled and dissolved in $100 \mathrm{ml}$ of $4 \%$ nitric acid and $2 \%$ hydrochloric acid. This solution was then analyzed by a combination of ICP-MS (Inductively Coupled Plasma-Mass Spectrometry) and ICP-AES (inductively-coupled plasma-atomic emission spectrometry) to determine major and trace element compositions of the samples. The obtained results were corrected for spectral inter-element interferences. Oxide concentration was calculated from the determined elemental concentration and the result was reported in that format. Loss on ignition (LOI) was measured by weight difference after ignition at $1000^{\circ} \mathrm{C}$. To certify data quality (95\% confidence level) and to calibrate the equipment for optimal precision, a replicate, standard and blank was measured. For the major oxides, the analytical 
uncertainties were about 0.01 wt\%, apart from $\mathrm{Fe}_{2} \mathrm{O}_{3}(0.04 \%)$. The detection limits for trace elements were variable as follow (in ppm): Ni (20); V (8); Ba, Sc, Be, Sn (1); Ga, Sr, W (0.5); Nd (0.3); Co, Th (0.2); Cs, Hf, Nb, Rb, Ta, U, Zr, Y, La, Ce (0.1); Sm, Gd, Dy, Yb (0.05); Er (0.03); Pr, Eu, Ho (0.02); Tb, Tm, Lu (0.01). The results are presented in Table 2.

\section{Results}

\subsection{Petrography and Structural Characteristics}

The studied dolerite dikes are vertical to subvertical and striking $\mathrm{N} 10^{\circ}-175^{\circ} \mathrm{E}$; their width and length generally range from 5 to $40 \mathrm{~m}$ and from 0.02 to $4 \mathrm{~km}$ respectively (Table 3 ). The petrographic study highlighted four facies of dolerites depending on the color and the mineralogical composition. These are: 1) pyrite and calcite-bearing dolerites, 2) pyrite-bearing dolerites with basement rock enclaves' rich, 3) pyrite-bearing dolerite and 4) amphibole and titanite-bearing dolerite with intergranular granophyric, typical doleritic, ophitic and ophitic with granophyre textures respectively. The primary mineralogical assemblage of these rocks is completely or partially transformed in some cases. Plagioclase and pyroxene are the dominant mineral phases.

\subsubsection{Pyrite and Calcite-Bearing Dolerites (PCD)}

Pyrite and calcite-bearing dolerites of Léré are observed at Teufoultréné and Lampagame localities. They outcrop in the form straight dykes constituted by bowls and blocks (Figure 3(a), Figure 3(c)) striking N10 - 30 $\mathrm{E}$ at Teufoultréné and $\mathrm{N} 165^{\circ}-175^{\circ} \mathrm{E}$ at Lampagame. Their width $(10-20 \mathrm{~m})$ and length $(1.2-4$ $\mathrm{km}$ ) fluctuate from one outcrop to another. Under polarized microscope, PCD are characterized by an intergranular granophyric texture (Figure 3(b), Figure 3(d)). For this texture, the interstices between the plagioclase laths are occupied by phenocrysts and microcrystals of olivine, clinopyroxene, pyrite, opaque minerals and calcite (Figure (3b)). The inclusions of accessory minerals such as opaque minerals and apatite are observed in certain sections as well as secondary minerals represented by epidote and chlorite.

\subsubsection{Pyrite-Bearing Dolerites with Xenoliths of Basement Rocks (PDxbr)}

The pyrite-bearing dolerites with enclave of basement rocks outcrop in bowls and blocks in the form of rectilinear dykes striking mainly $\mathrm{N} 45^{\circ}-135^{\circ} \mathrm{E}$ at Tréné, Berliang and in the bed of Mayo Kebbi River at Zabili (width: 5 - 15 m; length: $0.5-2 \mathrm{~km}$ ). The enclaves of basement rocks are granitic and essentially made up of alkali feldspars. Under polarized light, the dolerites show a classic doleritic texture (Figure 3(f)). PDxbr are composed of plagioclase laths phenocrysts and microcrystals of clinopyroxene, amphibole, pyrite, alkaline feldspar and opaque minerals. Plagioclase appears as microlites and phenocrysts that are generally fairly automorphic. Secondary minerals (epidote, chlorite) are also observed. 
Table 2. Major and trace elements for dolerites from Figuil and Léré.

\begin{tabular}{|c|c|c|c|c|c|c|c|c|c|c|}
\hline & \multicolumn{5}{|c|}{ Group I } & \multicolumn{5}{|c|}{ Group II } \\
\hline & $P C D$ & $P C D$ & $P C D$ & $P C D$ & $P D x b r$ & $P D x b r$ & $A T D$ & $A T D$ & $P D$ & $P D$ \\
\hline & TESM4 & TEIMB & TERM4 & $T L M B$ & $B e M B$ & ZiM2 & PmeM2 & PletM2 & FefMl & $F_{C V} M 1$ \\
\hline \multicolumn{11}{|l|}{$\mathrm{Wt} \%$} \\
\hline $\mathrm{SiO}_{2}$ & 45.7 & 45.87 & 45.97 & 44.09 & 46.05 & 46.45 & 48.28 & 55.87 & 43.85 & 48.67 \\
\hline $\mathrm{TiO}_{2}$ & 3.44 & 3.1 & 2.55 & 3.03 & 3.32 & 2.12 & 2.16 & 1.28 & 2.47 & 2.82 \\
\hline $\mathrm{Al}_{2} \mathrm{O}_{3}$ & 14.71 & 15.03 & 15.69 & 14.65 & 14.5 & 16.18 & 15.7 & 14.82 & 14.51 & 14.82 \\
\hline $\mathrm{Fe}_{2} \mathrm{O}_{3}$ & 15.64 & 15.39 & 13.76 & 15.15 & 16.83 & 11.91 & 12.34 & 7.13 & 12.73 & 12.09 \\
\hline $\mathrm{MnO}$ & 0.18 & 0.19 & 0.17 & 0.18 & 0.2 & 0.18 & 0.19 & 0.1 & 0.17 & 0.14 \\
\hline $\mathrm{MgO}$ & 4.68 & 4.34 & 4.96 & 4.41 & 4.07 & 7.41 & 6.33 & 5.3 & 7.58 & 6.48 \\
\hline $\mathrm{CaO}$ & 7.23 & 6.72 & 6.87 & 6.87 & 6.04 & 9.05 & 8.41 & 5.21 & 10.16 & 7.76 \\
\hline $\mathrm{Na}_{2} \mathrm{O}$ & 3.02 & 3.74 & 3.5 & 3.16 & 3.55 & 3.01 & 3.27 & 4.1 & 2.68 & 3.2 \\
\hline $\mathrm{K}_{2} \mathrm{O}$ & 1.94 & 1.26 & 1.38 & 1.16 & 1.31 & 1.04 & 0.87 & 3.53 & 1.37 & 1.08 \\
\hline $\mathrm{P}_{2} \mathrm{O}_{5}$ & 0.59 & 0.58 & 0.41 & 0.55 & 0.71 & 0.37 & 0.38 & 0.49 & 0.35 & 0.34 \\
\hline LOI & 2.5 & 3.4 & 4.4 & 6.4 & 3.1 & 2 & 1.8 & 1.7 & 3.7 & 2.2 \\
\hline Total & 99.69 & 99.71 & 99.73 & 99.71 & 99.71 & 99.73 & 99.75 & 99.73 & 99.69 & 99.7 \\
\hline $\mathrm{Mg} \#$ & 40.2 & 38.8 & 44.8 & 39.5 & 35.2 & 58.3 & 53.5 & 62.6 & 57.2 & 54.6 \\
\hline \multicolumn{11}{|c|}{ Traces (ppm) } \\
\hline $\mathrm{Sc}$ & 18.0 & 17.0 & 17.0 & 16.0 & 14.0 & 27.0 & 26.0 & 13.0 & 24.0 & 18.0 \\
\hline $\mathrm{Be}$ & 1.0 & 3.0 & 2.0 & 6.0 & 2.0 & $<1$ & $<1$ & 2.0 & $<1$ & 3.0 \\
\hline $\mathrm{V}$ & 272.0 & 200.0 & 189.0 & 204.0 & 221.0 & 225.0 & 218.0 & 133.0 & 291.0 & 260.0 \\
\hline Co & 50.9 & 45.7 & 47.4 & 48.6 & 49.2 & 46.6 & 43.8 & 26.3 & 50.1 & 45.1 \\
\hline $\mathrm{Ni}$ & 38.0 & 38.0 & 50.0 & 33.0 & 43.0 & 91.0 & 62.0 & 114.0 & 97.0 & 107.0 \\
\hline $\mathrm{Cr}$ & nd & nd & 13.68 & 13.68 & 20.53 & 150.52 & 60.42 & 260.00 & 157.37 & 177.89 \\
\hline $\mathrm{Ga}$ & 23.1 & 22.8 & 21.0 & 25.8 & 22.6 & 17.2 & 19.3 & 18.2 & 19.8 & 19.6 \\
\hline $\mathrm{Rb}$ & 37.6 & 21.1 & 23.6 & 18.4 & 18.3 & 29.4 & 11.9 & 99.0 & 18.9 & 21.5 \\
\hline $\mathrm{Sr}$ & 593.0 & 569.7 & 621.5 & 677.6 & 515.3 & 363.3 & 366.5 & 564.3 & 585.7 & 679.4 \\
\hline $\mathrm{Y}$ & 33.2 & 34.4 & 25.7 & 32.9 & 40.8 & 28.8 & 35.2 & 18.1 & 18.9 & 17.3 \\
\hline $\mathrm{Zr}$ & 298.0 & 290.1 & 223.4 & 280.0 & 391.4 & 177.8 & 201.4 & 271.5 & 170.5 & 172.8 \\
\hline $\mathrm{Nb}$ & 30.9 & 27.1 & 21.4 & 26.8 & 35.8 & 8.5 & 9.8 & 13.2 & 26.6 & 9.1 \\
\hline Sn & 2.0 & 2.0 & 2.0 & 2.0 & 3.0 & 1.0 & 1.0 & 1.0 & 2.0 & 1.0 \\
\hline Cs & 1.2 & 2.4 & 0.9 & 7.7 & 0.4 & 0.5 & 0.2 & 0.7 & 0.4 & 0.7 \\
\hline $\mathrm{Ba}$ & 674.0 & 653.0 & 463.0 & 449.0 & 613.0 & 199.0 & 210.0 & 972.0 & 373.0 & 428.0 \\
\hline $\mathrm{La}$ & 41.0 & 36.3 & 26.7 & 36.3 & 44.2 & 13.2 & 16.0 & 50.0 & 21.3 & 25.8 \\
\hline $\mathrm{Ce}$ & 90.5 & 81.8 & 60.3 & 76.9 & 100.1 & 33.6 & 40.4 & 97.8 & 45.2 & 54.2 \\
\hline $\operatorname{Pr}$ & 11.2 & 10.5 & 7.5 & 9.9 & 12.3 & 4.7 & 5.5 & 11.3 & 5.4 & 6.7 \\
\hline $\mathrm{Nd}$ & 46.7 & 42.3 & 31.9 & 41.5 & 51.4 & 21.7 & 24.9 & 44.3 & 23.6 & 27.9 \\
\hline $\mathrm{Sm}$ & 9.4 & 8.9 & 6.7 & 9.2 & 10.5 & 5.6 & 6.1 & 7.5 & 5.0 & 5.9 \\
\hline $\mathrm{Eu}$ & 2.8 & 2.7 & 2.1 & 2.6 & 3.1 & 1.9 & 2.1 & 1.9 & 1.7 & 2.0 \\
\hline $\mathrm{Gd}$ & 9.3 & 9.1 & 6.7 & 8.6 & 10.5 & 6.0 & 6.8 & 6.1 & 5.2 & 5.6 \\
\hline $\mathrm{Tb}$ & 1.2 & 1.3 & 1.0 & 1.2 & 1.5 & 1.0 & 1.1 & 0.8 & 0.8 & 0.7 \\
\hline Dy & 7.1 & 7.1 & 5.0 & 7.0 & 8.4 & 5.5 & 6.3 & 3.6 & 4.1 & 3.7 \\
\hline Ho & 1.3 & 1.3 & 1.0 & 1.3 & 1.5 & 1.1 & 1.4 & 0.6 & 0.8 & 0.7 \\
\hline Er & 3.4 & 3.6 & 2.7 & 3.3 & 4.3 & 3.0 & 3.7 & 1.7 & 2.0 & 1.7 \\
\hline
\end{tabular}




\begin{tabular}{|c|c|c|c|c|c|c|c|c|c|c|}
\hline \multicolumn{11}{|c|}{ Continued } \\
\hline $\mathrm{Tm}$ & 0.5 & 0.5 & 0.3 & 0.4 & 0.6 & 0.4 & 0.5 & 0.2 & 0.3 & 0.2 \\
\hline $\mathrm{Yb}$ & 2.8 & 2.8 & 2.2 & 2.7 & 3.5 & 2.8 & 3.4 & 1.3 & 1.7 & 1.3 \\
\hline $\mathrm{Lu}$ & 0.4 & 0.6 & 0.3 & 0.4 & 0.5 & 0.4 & 0.5 & 0.2 & 0.2 & 0.2 \\
\hline $\mathrm{Hf}$ & 7.2 & 7.0 & 5.6 & 6.5 & 9.2 & 4.2 & 4.9 & 6.4 & 4.1 & 4.6 \\
\hline $\mathrm{Ta}$ & 1.8 & 1.5 & 1.2 & 1.5 & 2.2 & 0.5 & 0.5 & 0.6 & 1.7 & 0.6 \\
\hline $\mathrm{W}$ & 0.7 & $<0.5$ & 0.8 & 1.2 & $<0.5$ & 0.5 & $<0.5$ & 1.4 & $<0.5$ & $<0.5$ \\
\hline $\mathrm{Th}$ & 3.0 & 2.4 & 2.1 & 1.9 & 3.2 & 0.6 & 1.0 & 7.6 & 1.7 & 3.6 \\
\hline $\mathrm{U}$ & 0.7 & 0.6 & 0.7 & 0.6 & 0.8 & 0.3 & 0.5 & 1.5 & 0.6 & 0.7 \\
\hline $\mathrm{Eu} / \mathrm{Eu}^{*}$ & 0.92 & 0.92 & 0.96 & 0.89 & 0.90 & 1.00 & 1.00 & 0.86 & 1.02 & 1.06 \\
\hline $\mathrm{Nb} / \mathrm{Nb}^{*}$ & 0.93 & 1.10 & 0.77 & 1.13 & 1.23 & 0.54 & 0.52 & 0.20 & 1.03 & 0.37 \\
\hline
\end{tabular}

$\mathrm{Mg \# ;} \mathrm{molar} \mathrm{ratio} \mathrm{of}[\mathrm{MgO} /(\mathrm{MgO}+\mathrm{FeO})] \times 100) ; \mathrm{Fe}_{2} \mathrm{O}_{3} / \mathrm{FeO}=0.15$.

Table 3. Petrographic and structural characteristics of the studied dykes. PCD: Pyrite and calcite-bearing dolerites; PDxbr: Pyrite-bearing dolerites with xenoliths of basement rocks; ATD: Amphibole and titanite-bearing dolerites; PD: Pyrite-bearing dolerites; Cpx: clinopyroxene; Pl: plagioclase; Ol: olivine; Opq: opaque; Cal: calcite; Amp: amphibole; Bt: biotite; Py: pyrite; Afs: alkali feldspar; Ap: apatite; Ttn: titanite; Ep: epidote; Chl: chlorite.

\begin{tabular}{|c|c|c|c|c|}
\hline & PCD & PDxbr & ATD & PD \\
\hline Orientation & $\mathrm{N} 10^{\circ}-175^{\circ} \mathrm{E}$ & $\mathrm{N} 45^{\circ}-135^{\circ} \mathrm{E}$ & $\mathrm{N} 45^{\circ}-157^{\circ} \mathrm{E}$ & $\mathrm{N} 23^{\circ}-45^{\circ} \mathrm{E}$ \\
\hline Width & $10-20 \mathrm{~m}$ & $5-15 m$ & $5-10 m$ & $20-40 m$ \\
\hline Length & $1.2-4 \mathrm{~km}$ & $0.5-2 \mathrm{~km}$ & $0.3-2 \mathrm{~km}$ & $20-200 m$ \\
\hline Mineralogy & $\begin{array}{c}\mathrm{Pl}+\mathrm{Cpx}+\mathrm{Ol}+ \\
\mathrm{Opq}+\mathrm{Cal}+\mathrm{Ap}+ \\
\mathrm{Ep}+\mathrm{Chl}+\mathrm{Py}\end{array}$ & $\begin{array}{c}\mathrm{Pl}+\mathrm{Afs}+\mathrm{Cpx}+ \\
\mathrm{Amp}+\mathrm{Opq}+\mathrm{Ep}+ \\
\mathrm{Chl}+\mathrm{Py}\end{array}$ & $\begin{array}{c}\mathrm{Pl}+\mathrm{Afs}+\mathrm{Cpx}+ \\
\mathrm{Amp}+\mathrm{Bt}+\mathrm{Opq}+ \\
\mathrm{Ap}+\mathrm{Ttn}+\mathrm{Ep}+\mathrm{Chl}\end{array}$ & $\begin{array}{c}\mathrm{Pl}+\mathrm{Afs}+\mathrm{Cpx}+ \\
\mathrm{Opq}+\mathrm{Ep}+\mathrm{Chl}\end{array}$ \\
\hline
\end{tabular}

\subsubsection{Amphibole and Titanite-Bearing Dolerites (ATD)}

The amphibole and titanite dolerites dykes of Poubamé and Poutalet are oriented $\mathrm{N} 152^{\circ}-159^{\circ} \mathrm{E}$; those of Zabili striking $\mathrm{N} 43^{\circ}-48^{\circ} \mathrm{E}$ with width of $5-10 \mathrm{~m}$ and length of $0.3-2 \mathrm{~km}$. They outcrop in the form of centimeter to decimetric bawls. Under the microscope, the dolerites show an ophitic texture (Figure 3(g)). ATD are characterized by clinopyroxene, plagioclase and amphibole phenocrysts. Alkali feldspar and biotite are also identified. Common accessory phases are oxides, apatite and titanite associated with epidote and chlorite.

\subsubsection{Pyrite-Bearing Dolerites (PD)}

At Figuil, pyrite-bearing dolerite dykes outcrop in the form of flagstones and bowls, striking $\mathrm{N} 23^{\circ}-45^{\circ} \mathrm{E}$ (width: $20-40 \mathrm{~m}$; length: $20-200 \mathrm{~m}$ ). Under the polarized microscope, PD present an ophitic texture with granophyre (Figure $3(\mathrm{~h})$ ). They consist of plagioclase laths, clinopyroxene, alkali feldspar crystals and plagioclase xenocrysts (Figure $3(\mathrm{~h})$ ). The plagioclase crystals are generally transformed into damourite. Secondary products include epidote and chlorite. 


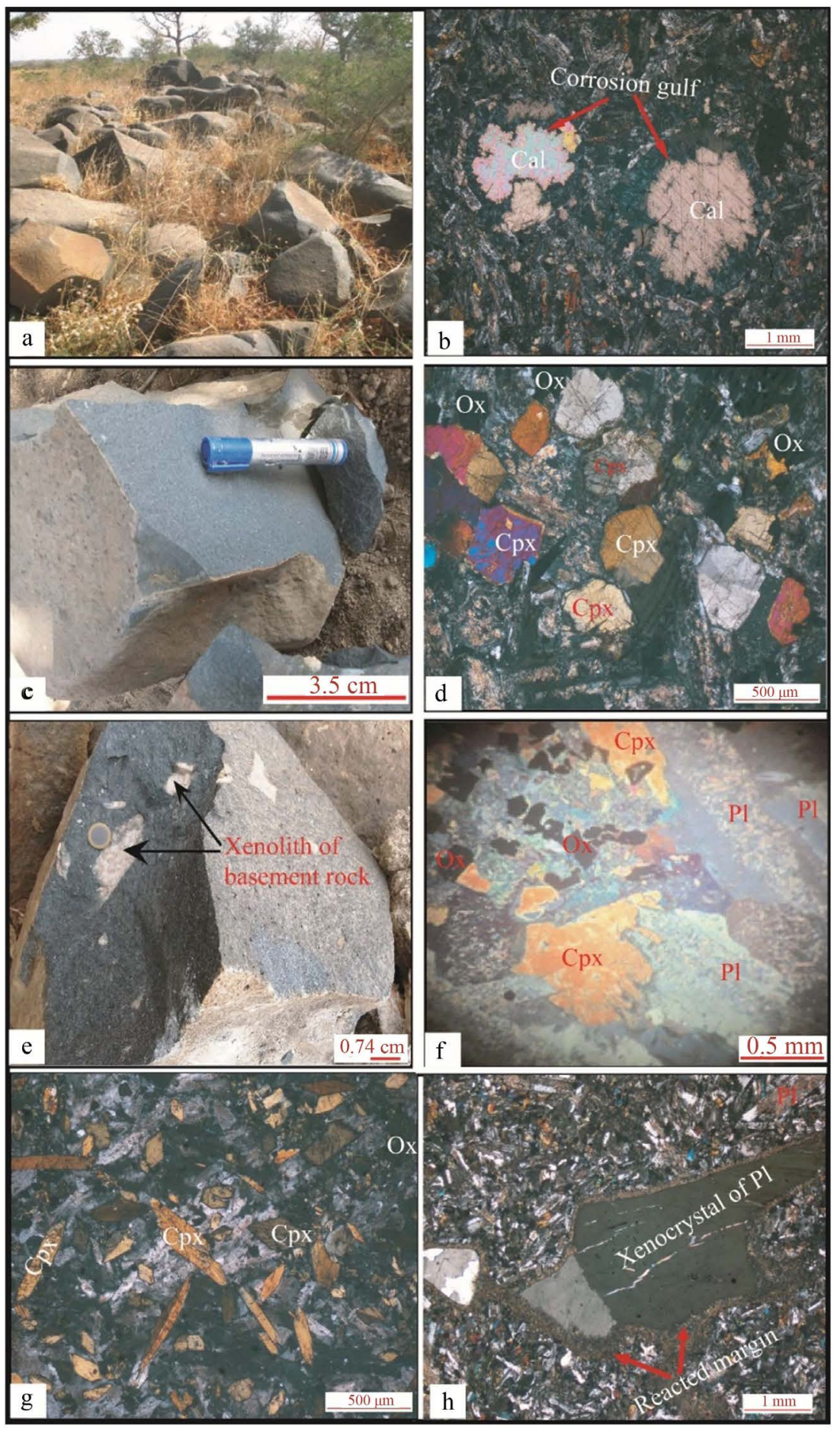

Figure 3. Aspect of some samples and microphotographs showing the structural and textural characteristics of dolerite. (a) Outcrop of a dolerite dyke in the form of bawls and blocks at Léré; (b) Microphotograph of pyrite and calcite-bearing dolerites showing calcite crystals with gulfs of corrosion; (c) Fresh sample of calcite-bearing dolerites of Léré; (d) intergranular texture with granophyre of calcite-bearing dolerites; (e) Sample of pyrite-bearing dolerites with xenoliths of basement rocks; (f) Doleritic dolerite texture of pyrite-bearing dolerites with xenoliths of basement rocks; (g) Ophitic texture of Amphibole and titanite-bearing dolerites of Poutalet (Léré); (h) Xenocrysts of plagioclase surrounded by a reactional margin in pyrite-bearing dolerites. 


\subsection{Geochemistry}

\subsubsection{Major Elements}

With the exception of a sample PletM2 (which is a trachy-andesite), all the rocks exhibits a basaltic composition which are basanite tephrite and basalt in the TAS classification of Le Bas et al. [30] (Figure 4) with a relatively homogeneous chemical composition: $43.85 \%<\mathrm{SiO}_{2}<48.67 \% ; 4.05 \%<\mathrm{Na}_{2} \mathrm{O}+\mathrm{K}_{2} \mathrm{O}<5 \% ; 11.91 \%<$ $\mathrm{Fe}_{2} \mathrm{O}_{3}<16.83 \% ; 4.04 \%<\mathrm{MgO}<7.58 \% ; 2.12 \%<\mathrm{TiO}_{2}<3.44 \% ; 14.5 \%<\mathrm{Al}_{2} \mathrm{O}_{3}<$ $16.18 \%$. The alkaline-subalkaline dividing line of Irvine and Baragar [31] show that dolerites are essentially alkaline (Figure 4).

The four groups of dolerites previously defined during petrographic descriptions are subdivided into two geochemical groups. Group I consists of calcite and pyrite-bearing dolerites and pyrite-bearing dolerites with enclave of basement rocks; Group II comprises amphibole and titanite-bearing dolerites and pyrite-bearing dolerites. In the AFM diagram of Ivrine and Baragar [31], almost all the analyzed samples are classify in tholeiitic series; only one sample of group II dolerite (PletM2 which seem to be contaminated) belong to calc-alkaline series (Figure 5). This is confirmed in $\mathrm{TiO}_{2}$ versus $\mathrm{Y} / \mathrm{Nb}$ diagram of Floyd and Winchester [32] where the majority of dolerites samples are plotted in the field of continental tholeiite (Figure 6). The two groups of dolerites are also clearly discriminated by their $\mathrm{MgO}$ contents and magnesium number $\mathrm{Mg} \#[(\mathrm{MgO} / \mathrm{MgO}+\mathrm{FeO}) \times 100]$ values which are relatively higher in group II (MgO: $5.3-7.41 \mathrm{wt} \%$; $\mathrm{Mg \# :} 53.5$ - 62.6) than in group I (MgO: 4.07 - $4.96 \mathrm{wt} \%$; Mg\#: 35.2 - 44.8) (Table 2). $\mathrm{TiO}_{2}$ (group I: 2.55 3.44 wt\%; group II: 1.28 - 2.47 wt\%) and $\mathrm{Fe}_{2} \mathrm{O}_{3}$ (group I: 13.76 - 16.83 wt\% group II: $7.13-12.73 \mathrm{wt} \%)$ concentrations also differentiate the two groups of dolerites.

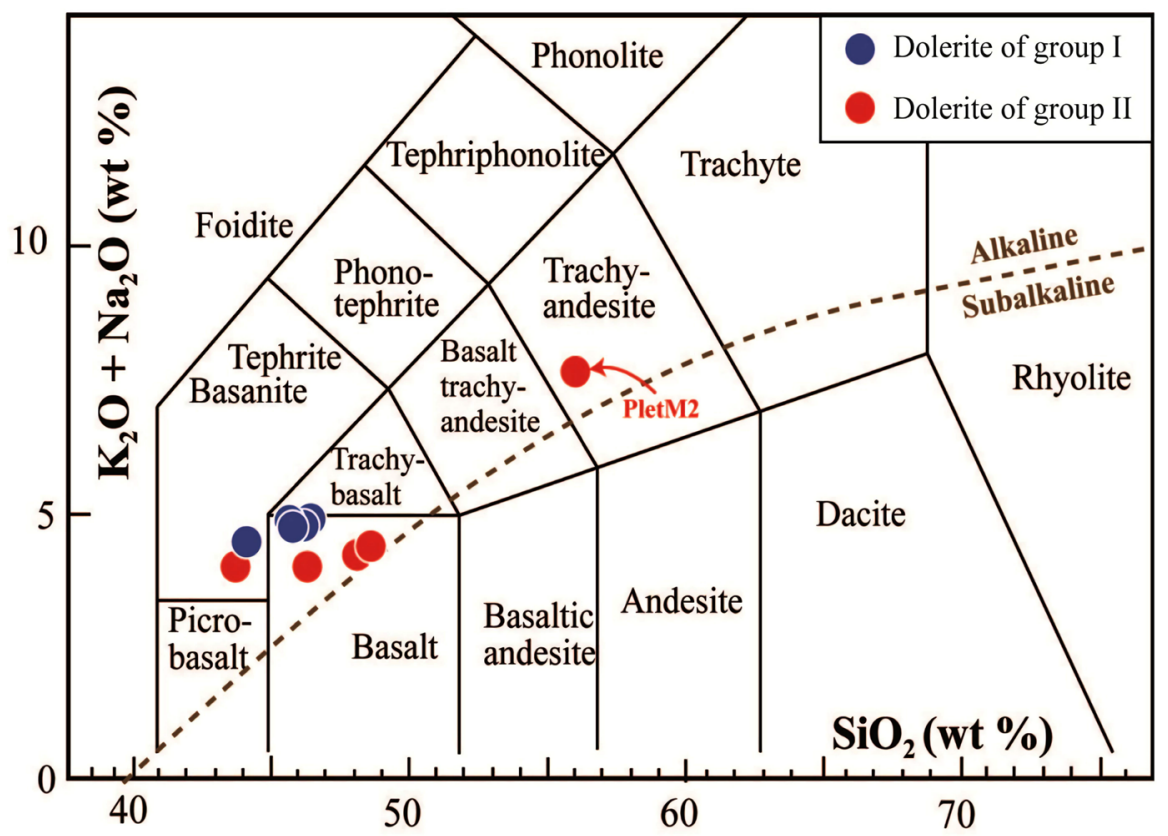

Figure 4. Total alkali vs. silica classification diagram after Le Bas et al. [30]); the alkaline-subalkaline dividing line is from Irvine and Baragar [31]. 


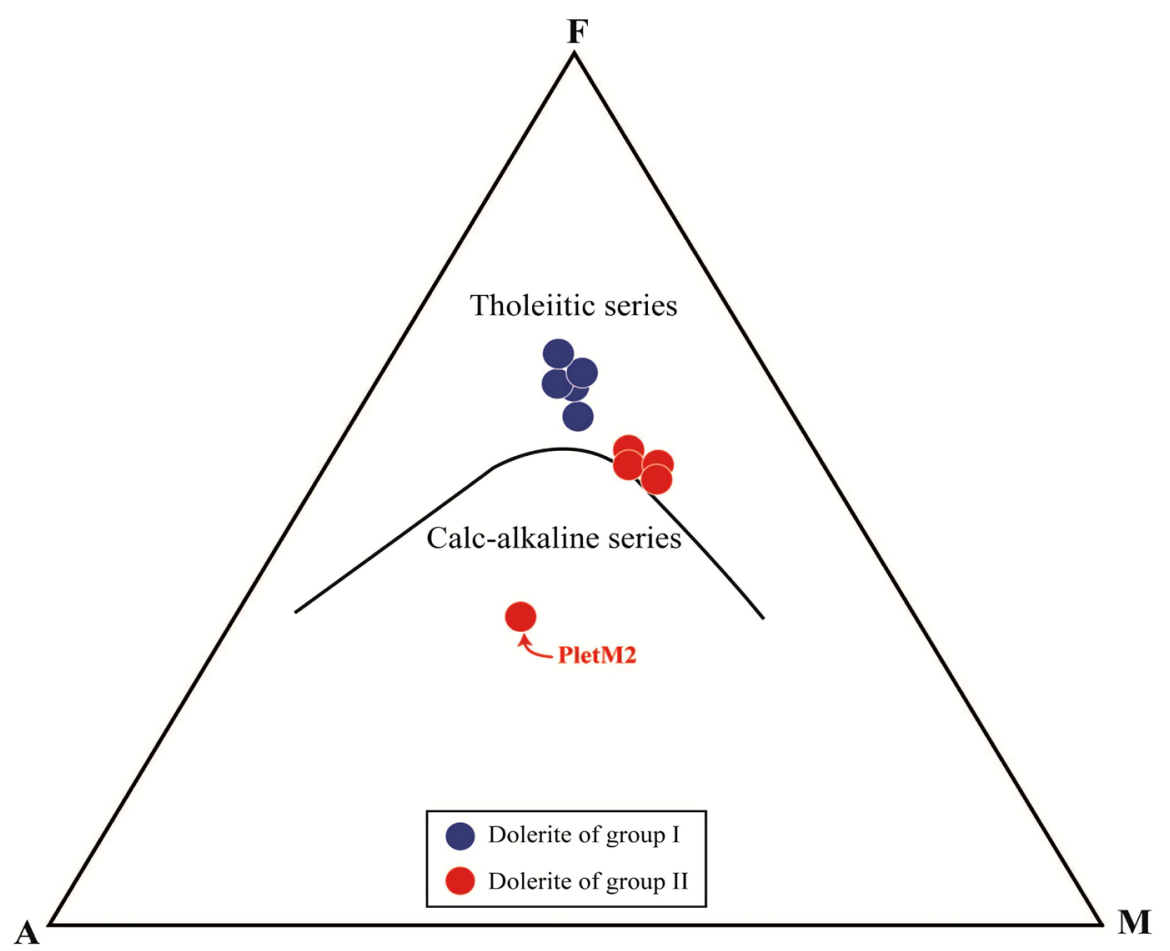

Figure 5. AFM diagram of Ivrine and Baragar [31] showing geochemical affinities of the Figuil and Léré dolerites. A: $\mathrm{Na}_{2} \mathrm{O}+\mathrm{K}_{2} \mathrm{O} ; \mathrm{F}: \mathrm{FeO}_{t} ; \mathrm{M}: \mathrm{MgO}$.

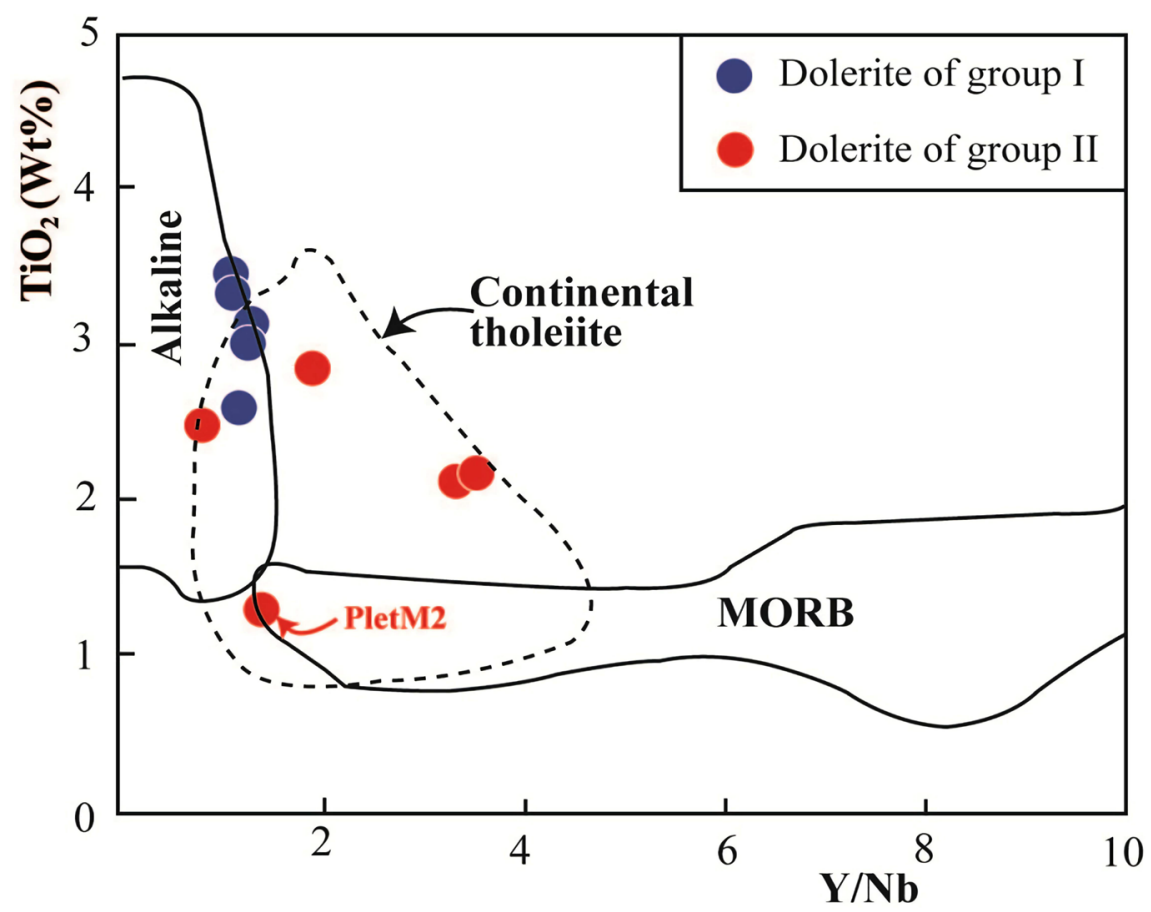

Figure 6. $\mathrm{TiO}_{2}$ versus $\mathrm{Y} / \mathrm{Nb}$ diagram of Figuil and Léré dolerite (after Floyd and Winchester, [32]).

Major elements variation diagrams with each oxide are plotted against $\mathrm{MgO}$ wt\% (Figure 7). In each group, the contents of major element oxides such as $\mathrm{Fe}_{2} \mathrm{O}_{3} \mathrm{t}$, 
$\mathrm{TiO}_{2}, \mathrm{Na}_{2} \mathrm{O} \mathrm{K}{ }_{2} \mathrm{O} \mathrm{MnO}$, and $\mathrm{P}_{2} \mathrm{O}_{5}$ decrease with increasing $\mathrm{MgO}$ (Figures 7(a)-(f)), while those of $\mathrm{Al}_{2} \mathrm{O}_{3}$ and $\mathrm{CaO}$ increase with increasing $\mathrm{MgO}$ (Figure $7(\mathrm{~g})$, Figure $7(\mathrm{~h})$ ). The samples of group I show no variation in $\mathrm{SiO}_{2}$ content, while those of group II display negative correlation in $\mathrm{SiO}_{2}$ content with $\mathrm{MgO}$ (Figure 7(i)).

\subsubsection{Trace Elements}

The concentrations of transition elements of the dolerites, in particular $\mathrm{Cr}, \mathrm{Ni}, \mathrm{V}$ and Co are $100-380$ ppm, 38 - 114 ppm, 133 - 272 ppm and 26.30 - 50.90 respectively (Table 1). The two groups of dolerites are also distinguished by their $\mathrm{REE}, \mathrm{Ba}, \mathrm{Nb}, \mathrm{Zr}, \mathrm{La}$ and $\mathrm{Hf}$ contents which are relatively higher in group I than in group II. Group II, on the other hand, has higher $\mathrm{Sc}$, Ni and $\mathrm{Cr}$ contents compare to Group I (Table 2, Figure 8). In each group, the contents of $\mathrm{Sc}, \mathrm{Ni}, \mathrm{Cr}$
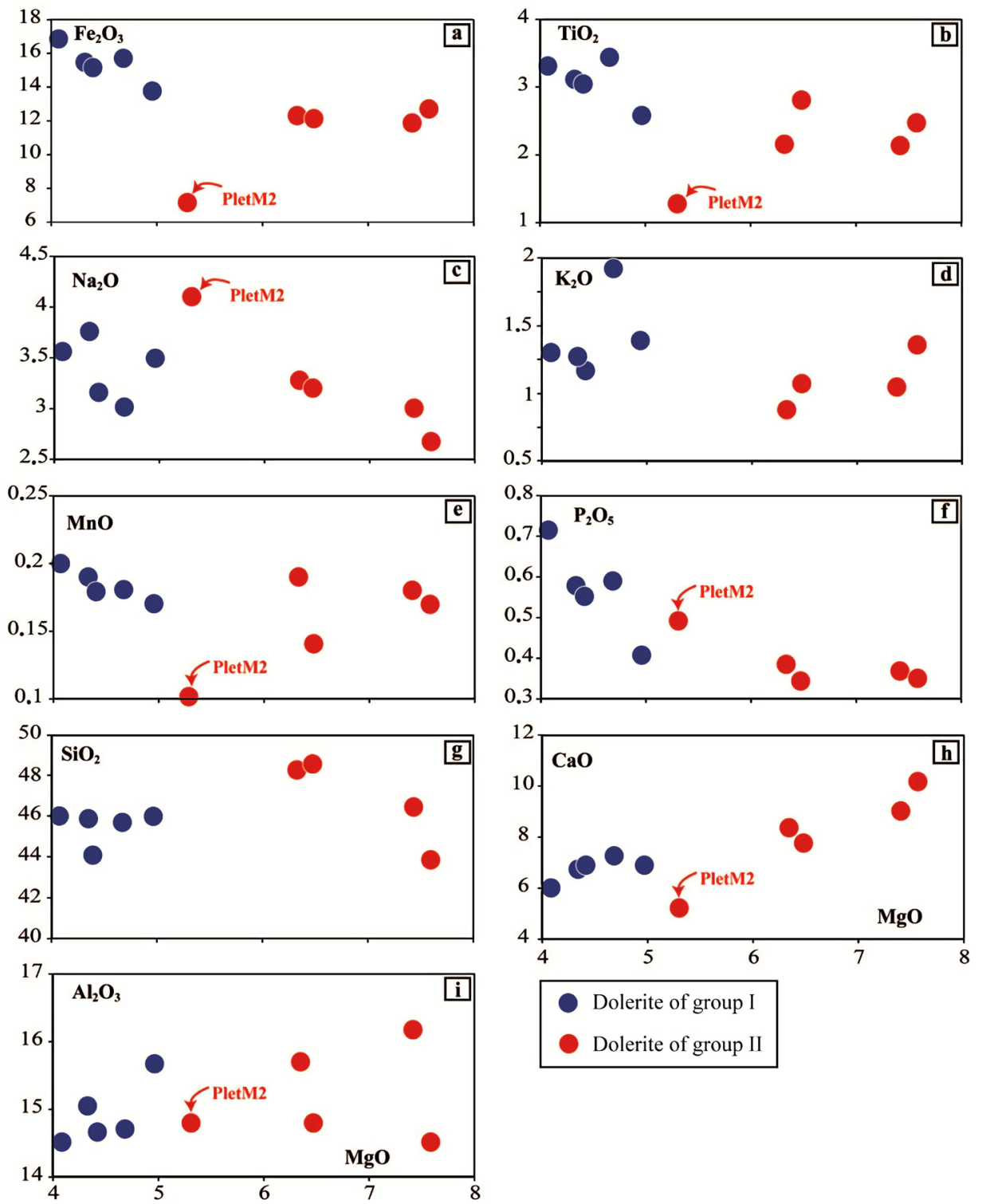

Dolerite of group I

Dolerite of group II

Figure 7. Harker diagrams of major elements versus MgO. Sample PletM2 which seem to be contaminated is identified in some diagrams. 

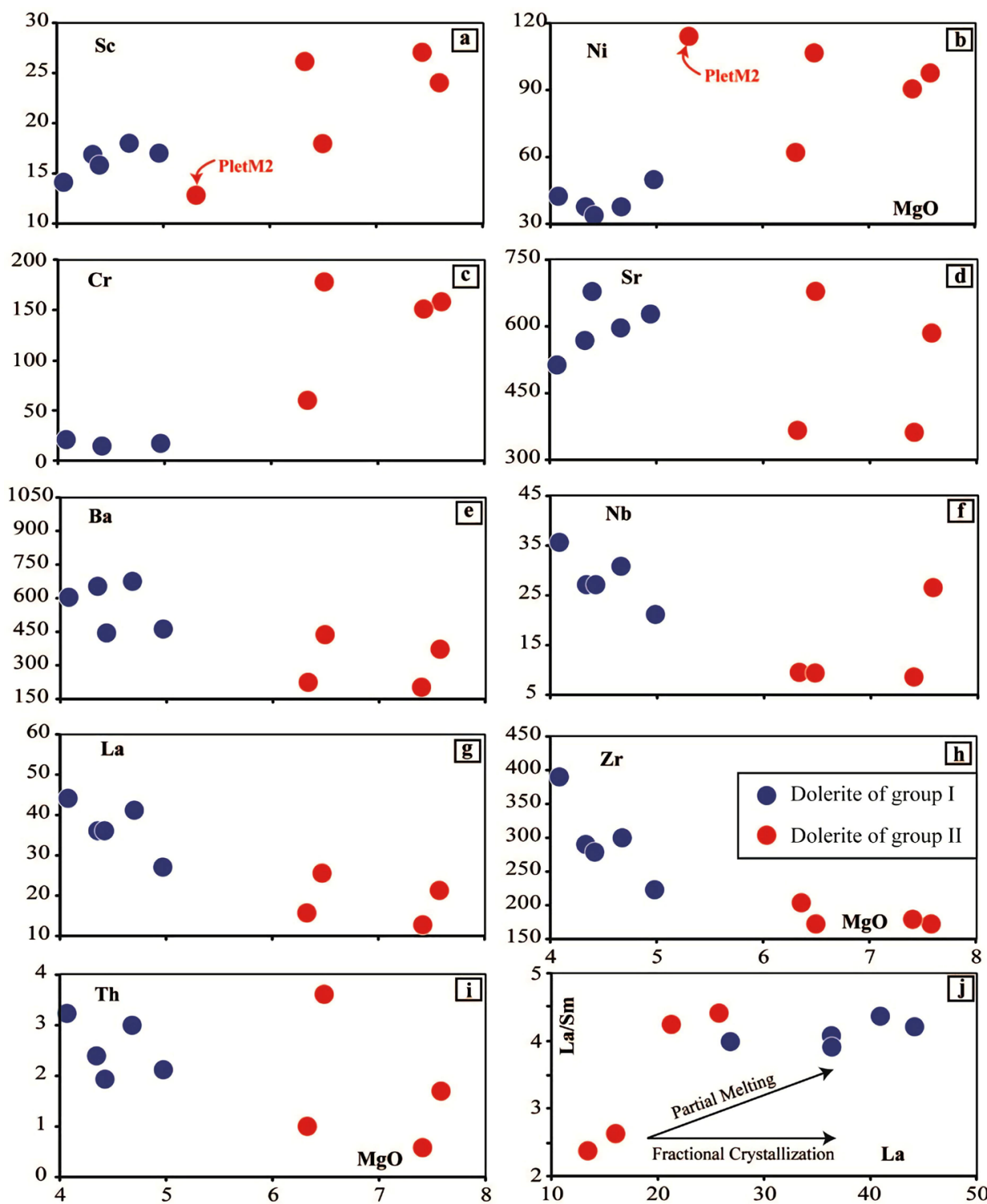

Figure 8. Harker diagrams of trace elements versus $\mathrm{MgO}(\mathrm{a}-\mathrm{i})$ and characterization of geologic processes (fractional crystallization and partial melting) of the analyzed diorites using $\mathrm{La} / \mathrm{Sm}$ versus La diagram ( $j$ ). Sample PletM2 is identified and removed in other diagrams.

and $\mathrm{Sr}$ exhibit positive correlation with $\mathrm{MgO}$ (Figures 8(a)-(d)), while $\mathrm{Ba}, \mathrm{Nb}$, $\mathrm{La}, \mathrm{Zr}$ and $\mathrm{Th}$ show negative correlation with $\mathrm{MgO}$ (Figures 8(e)-(i)). Figure 9(a) and Figure 9(c) are Chondrite normalized [33] REE patterns for samples from Figuil and Léré. According to chondrite normalized $(\mathrm{La} / \mathrm{Yb})_{\mathrm{N}}$ ratio, these patterns are generally similar and characterized by the fractionation of Light REE relative to Heavy REE. The dolerites of group I exhibit relatively high $(\mathrm{La} / \mathrm{Yb})_{\mathrm{N}}$ ratios $\left(8.24\right.$ - 10.01) whereas the group II show low values of $(\mathrm{La} / \mathrm{Yb})_{\mathrm{N}}$ ratios $(3.23$ 8.71). The rocks also show slightly negative $\mathrm{Eu}$ anomalies for group I dolerites $\left(\mathrm{Eu} / \mathrm{Eu}^{*}=0.89-0.96\right)$ to somewhat negative to positive $\mathrm{Eu}$ anomalies for group II dolerites $\left(\mathrm{Eu} / \mathrm{Eu}^{*}=0.86-1.06\right)$. The Primitive mantle normalized (Sun and McDonough, 1989) patterns show a negative anomalies in Th, Sm, Ti and positive 


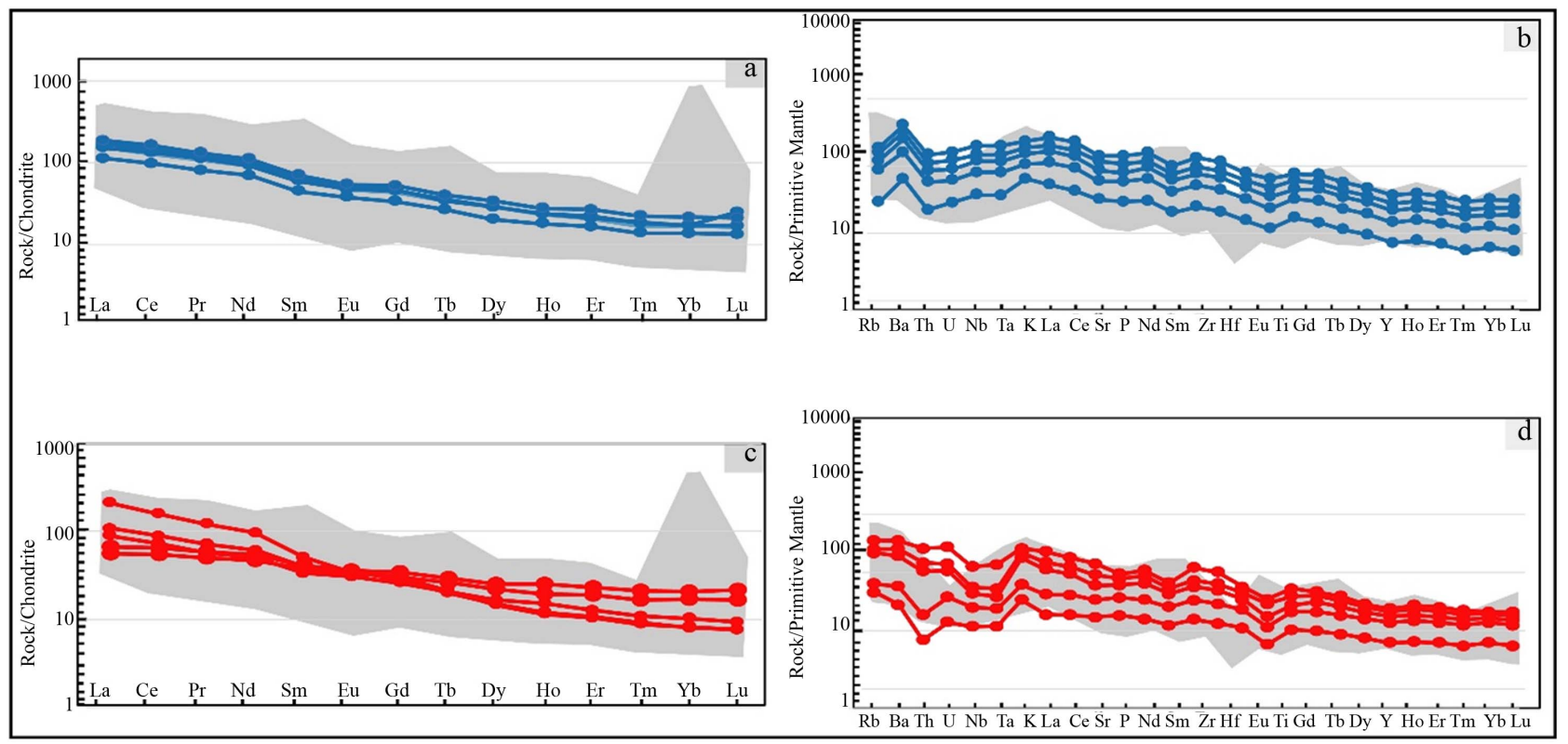

Figure 9. Chondrite-normalized REE patterns for dolerite of group I (a) and group II (c). Primitive mantle-normalized multi-element patterns for dolerite of group I (b) and group II (d). Normalizing values data are from [33]. The gray part of the diagrams represents dolerites of Mayo Oulo-Lere [10], Biden [61], Maham, Kendem, Dschang, Mnajo and Banganté [6] [60] and of Mbaoussi [7] which are added for comparison.

anomalies in $\mathrm{Ba}, \mathrm{Zr}$ and $\mathrm{Th}$ for dolerites of group I (Figure 9(b)). There is a positive anomalies in $\mathrm{K}, \mathrm{Zr}$, $\mathrm{Hf}$ and negative anomalies in $\mathrm{Ti}$, Th and $\mathrm{Sm}$ for group II dolerites (Figure 9(d)). The dolerites of group II also display negative to slightly positive $\mathrm{Nb}-\mathrm{Ta}$ anomalies $\left(\mathrm{Nb} / \mathrm{Nb}^{*}=0.20-1.23\right)$; these negative anomalies are most important in group II dolerite (Figure 9(d), Table 2).

\section{Discussion}

\section{Petrogenesis of Léré and Figuil Dolerites}

\section{1) Fractional crystallization and crustal contamination}

The contents of $\mathrm{Ni}, \mathrm{Cr}$ and $\mathrm{Co}$ for dolerites from Léré and Figuil are in equilibrium with mantle peridotites [34] or far from the probable composition of melts equivalent to primitive mantle (Ni: $300-400$ ppm, Cr: 300 - 500 ppm, Co; 50 70 ppm, Mg\#: 68 - 72, [35] [36]. These characteristics suggest that they underwent extensive fractional crystallization from parental magmas either en route to the surface or in magma chambers [37].

The observed behavior of trace elements and major element oxides of dolerites are reliable with the crystallization of Fe-Ti oxide, clinopyroxene, and plagioclase which are the most important mineral phases. The constant decrease in $\mathrm{Fe}_{2} \mathrm{O}_{3} \mathrm{t}$ and $\mathrm{TiO}_{2}$ when plotted against $\mathrm{MgO}$ (Figure 7(a), Figure 7(b)), shows a stage of fractionation of Fe-Ti oxides during the cooling of the magma. The crystallization of olivine and clinopyroxene is expressed by a decrease in $\mathrm{Sc}, \mathrm{Ni}, \mathrm{Cr}$ and $\mathrm{CaO}$ (Figure 7(h) and Figures 8(a)-(c)) concentrations with decreasing $\mathrm{MgO}$ contents. The constant increase of $\mathrm{Al}_{2} \mathrm{O}_{3}$ concentrations throughout nearly all the fractionation process shows that plagioclase was not a significant crystallizing phase during 
the differentiation of magma. This is also reliable with the absence or slight Sr or Eu depletion or negative anomalies even in the most differentiated samples (Figure 9). Nevertheless, the negative correlation of $\mathrm{SiO}_{2}$ content with $\mathrm{MgO}$ observed in group II dolerites may be linked to the presence of plagioclase as seen in the thin section (FcvM1, Figure 2(h)). But this plagioclase is a xenocrystal and is therefore not linked to doleritic magma. The inconsiderable negative correlation of $\mathrm{Na}_{2} \mathrm{O}$ and $\mathrm{K}_{2} \mathrm{O}$ with $\mathrm{MgO}$ associated to large variation of $\mathrm{Y} / \mathrm{Nb}(0.71-3.59)$ and nearly constant $\mathrm{Ba} / \mathrm{La}(12.37$ - 19.44) demonstrate that there are no crystallization of alkali feldspar [38] [39]. Low amounts of $\Sigma$ REE (100.9 - 252.4 ppm) combined with slightly negative or positive Eu anomaly is attributed to the crystallization of amphibole, apatite and/or plagioclase [40]. Nb negative anomaly in most dolerite samples of group II (Figure 10) could evidence the presence of amphibole in the metasomatized mantle [41]. The ratio $(\mathrm{La} / \mathrm{Yb})_{\mathrm{N}}$ varies between 3.38 and 14.24 showing a clear indication of REE fractionation. The $(\mathrm{Ce} / \mathrm{Sm})_{\mathrm{N}}$ ratio varies between 1.50 and 2.41 and $(\mathrm{Eu} / \mathrm{Yb})_{\mathrm{N}}$ between 1.81 and 2.93 all fluctuate in comparable ways and suggest a crystallization of minerals that including LREE (apatite) likewise for those integrate HREE in their crystalline structures (sphene). Diagrams of ratios of high to slightly incompatible elements La/Sm versus incompatible elements La (Figure $8(\mathrm{j})$ ), produce almost linear depicting for fractional crystallization and high gradient lines showing partial melting [42].

Fractional crystallization process was possibly combined with minor crustal contamination as shown by enrichment of $\mathrm{Th} / \mathrm{Yb}$ from group II to group I that might be due to turbulent emplacement (Figure 11, [43]). This has been observed in other continental tholeiites worldwide [44]-[51]. Through assimilation and fractional crystallization processes, magmas progression en route to the surface, evolving through fractionation, would have assimilated fragments of continental crust.

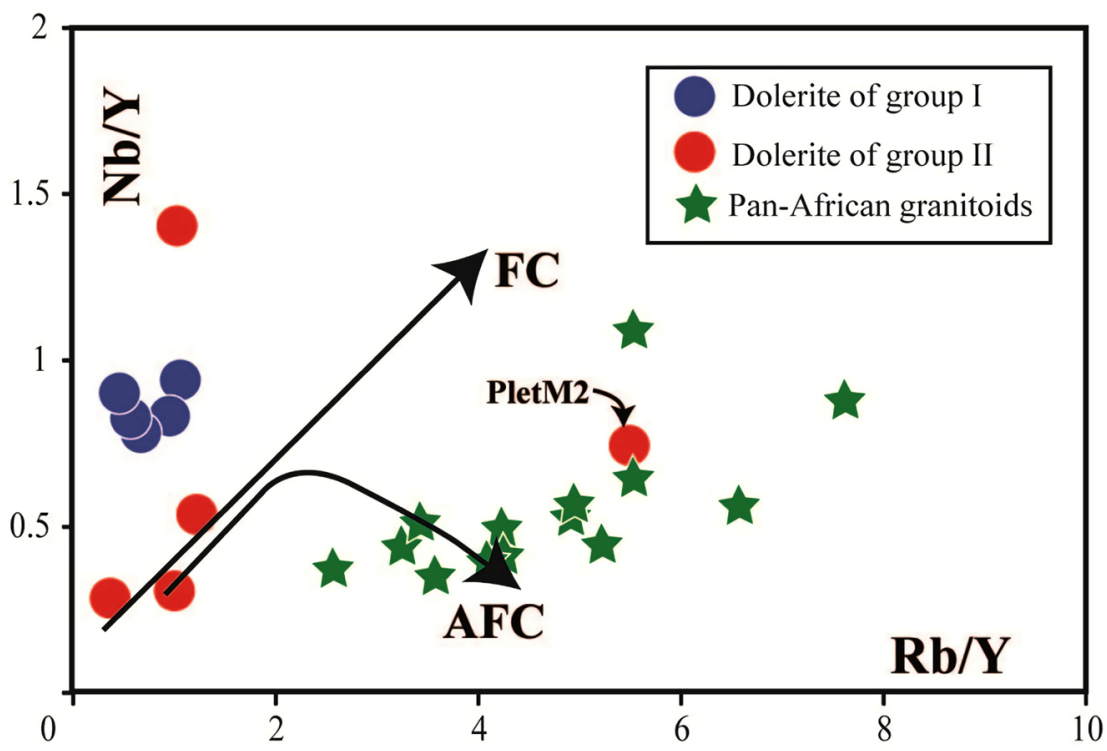

Figure 10. Nb/Y vs. Rb/Y after Cox and Hawkesworth [51] and Leeman and Hawkesworth [53] showing basement samples relative to the dolerite compositions. Data for Precambrian basement are from Sep Nlomngan et al. [40]. 


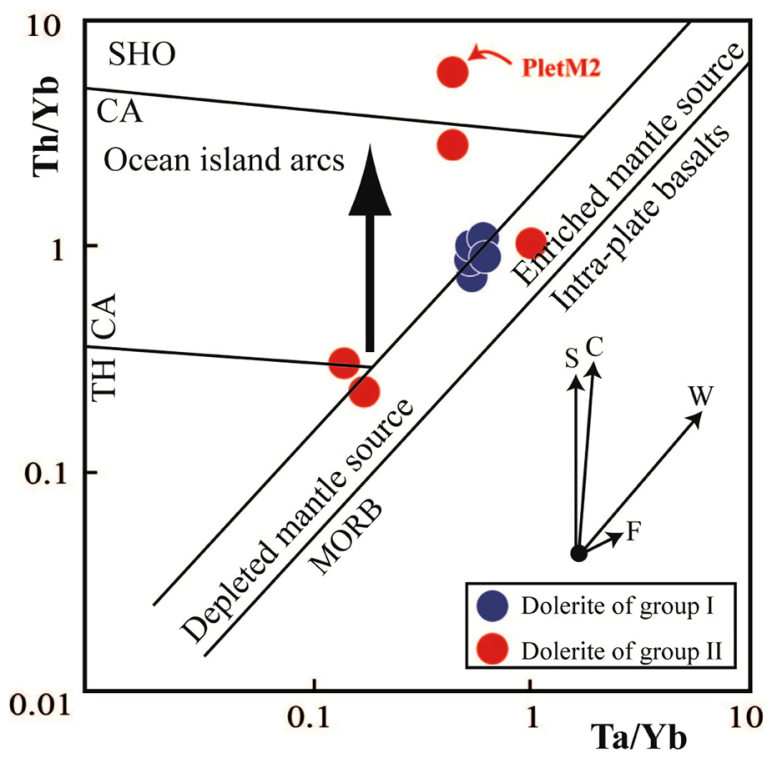

Figure 11. Th/Yb vs. Ta/Yb diagram (after [43] Pearce, 1982). S: enrichment related to subduction zone; C: crustal contamination; W: intra plate enrichment; F: fractional crystallization; TH: tholeiitic; CA: calc-alkaline; SHO: shoshonitic.

With higher concentrations of incompatible elements and LREE, group I dolerites ( REE: 126.4 - $208 \mathrm{ppm}$ ) resulted from group II ( REE: 73.2 - $114.6 \mathrm{ppm}$ ) through continuous crystallization of its mineral phases.

$\mathrm{The} \mathrm{Rb} / \mathrm{Y}$ vs. $\mathrm{Nb} / \mathrm{Y}$ diagram of Cox and Hawkesworth [52] and Leeman and Hawkesworth [53] can also be used to monitor the impact of the crustal assimilation over fractional crystallization on magma compositions. The dolerites of Figuil and Léré have low $\mathrm{Rb} / \mathrm{Y}$ ratios $(0.45$ - 1.24) compare to high values (2.54 7.64) of this ratio in Pan-African granitoids of this area, suggesting a limited effect of crustal contamination (Figure 10). Only one sample of dolerite of group II (PletM2) seem to be really contaminated because it is in the field of basement rocks. The group 1 dolerites which are most far away from the granitoids field appear to be the least contaminated. This point of view is supported by the presence of more marked $\mathrm{Nb}$-Ta negative spikes in group II dolerites (Figure (9d)) suggesting somewhat significant crustal contamination [54].

\section{2) Mantle source and melting}

The studied doleritic magma migrated through continental Pan African granitoid and thus the origin of the dolerite from the melting of the continental crust cannot be excluded. Nevertheless, incompatible trace elements ratios, principally $\mathrm{Rb} / \mathrm{Zr}$ and $\mathrm{Ba} / \mathrm{Nb}$ (LILE/HFSE) are greater in the Pan-African granitoids rocks from Boula Ibi (North Cameroun) (0.12 - 4.13 and 28.11 - 245.18, respectively; [40]) than those of Léré and figuil dolerites (0.05- 0.11 and $14.02-24.1)$ and therefore preclude the derivation of the studied dolerites directly from the melting of the continental crust. During anatexis of the continental crust, LILE are more compatible than HFSE, this is the reason why Melting of rocks from the continental crust preserve or increase rations of LILE/HFSE [55] [56] [57]. Low $(\mathrm{Ce} / \mathrm{Yb})_{\mathrm{N}}$ values (3.3 - 11.58) suggest fairly high partial melting degree of the source. 
The ratios of $\mathrm{Zr} / \mathrm{Hf}$ and $\mathrm{Nb} / \mathrm{Ta}$ of dolerites of group I (39.89 - 43.08 and 16.27 - 18.07), respectively) are comparable to those of group II (37.57 - 42.42 and 15.17 - 19.60), respectively), signifying that both series are co-genetic.

The existence of garnet in the mantle source is justified by the general depletion of HREE and LREE enrichment (Assah et al., 2015). (La/Yb) $)_{\mathrm{N}}$ ratios (normalizing values of Sun and MCDonough [33] respectively $\mathrm{La}=0.237$ and $\mathrm{Yb}=$ $0.17 \mathrm{ppm}$ ) are generally used to discriminate spinel-rich and garnet mantle sources: ratios $>5$ identify garnet-bearing mantle, while ratios $<5$ identify spinel-bearing mantle [58]. Most dolerite samples show higher REE concentrations and $(\mathrm{La} / \mathrm{Yb})_{\mathrm{N}}$ ratios fluctuating from 8.71 to 27.59 characterizing a garnet-bearing mantle. The nature of doleritic magma source is also supported by their $(\mathrm{Tb} / \mathrm{Yb})_{\mathrm{N}}>1.9(1.95$ 2.85) and $\mathrm{Dy} / \mathrm{Yb}>2(2.27$ - 2.85) ratios of most samples which suggests melting in a garnet-bearing mantle [58] [59]. Only two samples (ZiM2 and PmeM2) of group II dolerite belong to spinel-bearing mantle with $(\mathrm{La} / \mathrm{Yb})_{\mathrm{N}},(\mathrm{Tb} / \mathrm{Yb})_{\mathrm{N}}$ and $\mathrm{Dy} / \mathrm{Yb}$ ratios of $3.38, \leq 1.62$ and $\leq 1.96$ respectively.

\section{3) Geotectonic Context}

In the AFM diagram of Ivrine and Baragar [31], the analyzed samples are classified in tholeiitic series (Figure 5). This geotectonic context is confirmed by a binary $\mathrm{Zr} / \mathrm{Y}$ vs. Zr diagram of geotectonic discrimination [60] of basaltic rocks where the dolerites are plot in within-plate basalts field (Figure 12(a)). The Nb-Zr-Y triangular diagram of Meschede [61] which also proposed the geotectonic context of basaltic rocks (Figure 12(b)) defines the dolerites of Figuil and Léré as within-plates basaltic rocks with group II dolerite compositions fall within the field of tholeiitic basalts (AI and C) and group I within the field of alkali basalts (AI). Only sample PletM2 is not classify in the two diagrams.
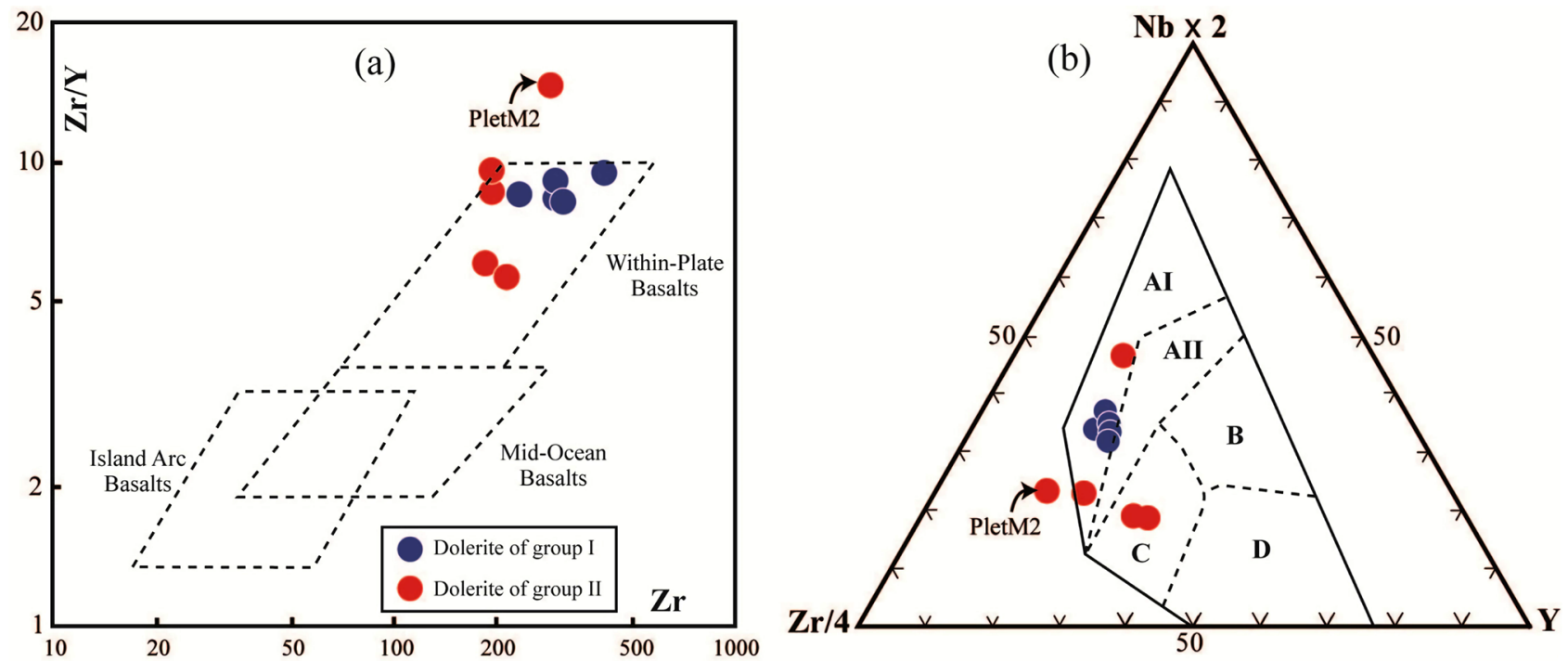

Figure 12. (a) Zr/Y vs. Zr diagram of basaltic rocks [58] (Pearce, 1979) showing the localisation of the studied dolerites in the field of within-plate basalts. (b) Zr/4-2Nb-Y ternary diagram of Meschede [59] showing the geotectonic context of figuil and Léré dolerites. AI: Within-plate alkali basalts; AII: Within-plate alkali basalts and Within-plate tholeiite; B: E-type MORB; C: Within-plate tholeiite and volcanic arc basalt; D: N-type MORB and volcanic arc basalt. 
Figuil and Léré dolerites resemble other dolerites described as continental tholeiites in Cameroon, e.g. at Dschang, Bangangté and Manjo [62], Biden [63], Mbaoussi [7], Bafoussam [5], Mayo Oulo-Léré and Babouri-Figuil [10].

\section{Conclusion}

Dolerites of Figuil and Léré are alkaline and exhibit basaltic compositions which are basanite tephrite and basalt; only one sample is a trachy-andesite. Based on the mineralogical composition and geochemical studies, two distinct groups of dolerites are identified: 1 ) the group of pyrite calcite bearing dolerites and pyrite bearing dolerites with alkali feldspars rich basement rock enclaves and 2) the group of pyrite bearing dolerites and amphibole titanite bearing dolerites. The mineralogical assemblage of these dolerites of alkaline composition consists of plagioclases, pyroxenes, oxides, amphibole, apatite, biotite and sometimes pyrite and calcite. The two groups of dolerites are also discriminated by their $\mathrm{TiO}_{2}$, $\mathrm{Fe}_{2} \mathrm{O}_{3}$, REE, $\mathrm{Ba}, \mathrm{Nb}, \mathrm{Zr}$, La and $\mathrm{Hf}$ contents which are relatively higher in group I than in group II. Group II, on the other hand, has higher $\mathrm{MgO}, \mathrm{Mg \#}, \mathrm{Sc}, \mathrm{Ni}$ and $\mathrm{Cr}$ contents compare to Group I. Figuil and Léré dolerites comprise two cogenetic groups and constitute a series evolving by fractional crystallization with some contribution of the continental crust. With higher concentrations of incompatible elements and LREE, group I dolerites resulted from group II through continuous crystallization of its mineral phases. The higher REE contents and $(\mathrm{La} / \mathrm{Yb})_{\mathrm{N}}>$ 8.7, $(\mathrm{Tb} / \mathrm{Yb})_{\mathrm{N}}>1.9$ and $\mathrm{Dy} / \mathrm{Yb}>2$ ratios characterize a garnet-bearing mantle. The continental tholeiitic signature of the studied dolerites is highlighted in geotectonic discrimination diagrams and also confirms the tholeitic nature of Cameroon dolerites.

\section{Acknowledgements}

This paper is a part of doctoral research being done by Klamadji Moussa Ngarena. Anonymous reviewers are thanked for useful remarks which helped us to improve the manuscript.

\section{Conflicts of Interest}

The authors declare no conflicts of interest regarding the publication of this paper.

\section{References}

[1] Ernst, R.E. and Buchan, K.L. (2001) Large Mafic Magmatic Events through Time and Links to Mantle-Plume Heads. In: Ernst, R.E. and Buchan, K.L., Eds., Mantle Plumes. Their Identification through Time, Geological Society of America Special Papers, Vol. 352, 483-575. https://doi.org/10.1130/0-8137-2352-3.483

[2] Bleeker, W. (2004) Taking the Pulse of Planet Earth: A Proposal for a New Multi-Disciplinary Flagship Project in Canadian Solid Earth Sciences. Geoscience Canada, 31, 179-190.

[3] Srivastava, R.K. (2011) Dyke Swarms: Keys for Geodynamic Interpretation. Springer-Verlag, Berlin. https://doi.org/10.1007/978-3-642-12496-9 
[4] Tchouankoué, J.P., Simeni Wambo, N.A., Kagou Dongmo, A. and Wörner, G. (2012) Pétrologie, géochimie et implications géodynamiques de la digue basaltique des essaims provenant de la partie continentale du Sud du volcanique camerounais Line. Afrique Centrale. The Open Geology Journal, 6, 72-84. https://doi.org/10.2174/1874262901206010072

[5] Kouankap Nono, G.D., Wotchoko, P., Ganno, S., Ngong Njinchuki, D., Nzenti, J.P. and Suh Cheo, E. (2013) Petrochemical Characterization of Two Distinct Types of Dolerites from Bafoussam Area, West Cameroon. International Journal of Geosciences, 4, 1131-1144. https://doi.org/10.4236/ijg.2013.48107

[6] Tchouankoué, J.P., Simeni Wambo, N.A., Kagou Dongmo, A. and Li, X.-H. (2014) 40Ar/39Ar Dating of Basaltic Dykes Swarm in Western Cameroon: Evidence of Late Paleozoic and Mesozoic Magmatism in the Corridor of the Cameroon Line. Journal of African Earth Sciences, 93, 14-22. https://doi.org/10.1016/j.jafrearsci.2014.01.006

[7] Nkouandou, O.F., Dourwe, D.P. and Mefire, F.A. (2016) Geochemistry and Petrogenesis of Mafic Doleritic Dykes at Mbaoussi (Adamawa Plateau. Cameroon. Central Africa). Journal of Geography Environment and Earth Science International, 8, 1-18. https://doi.org/10.9734/JGEESI/2016/28198

[8] Tchaptchet, T.D., Simeni Wambo, N.A., Keutchafo Kouamo, N.A., Tchouankoue, J.P. and Cucciniello, C. (2017) Geology, Mineralogy and Geochemistry of the Kekem Dyke Swarm (Western Cameroon): Insights into Paleozoic-Mesozoic Magmatism and Geodynamic Implications. Compte Rendus Geoscience, 349, 175-185. https://doi.org/10.1016/j.crte.2017.02.005

[9] Keutchafo Kouamo, N.A., Tchaptchet, T.D., Tezanou Ngueguim, A.L., Simeni Wambo, N.A., Tchouankoue, J.P. and Cucciniello, C. (2019) Petrogenesis of Basaltic Dikes from the Manjo Area (Western Cameroon): Insights into the Paleozoic Magmatism at the Northern Margin of the Congo Craton in Cameroon. Arabian Journal of Geosciences, 12, 281. https://doi.org/10.1007/s12517-019-4424-y

[10] Ngounouno, I., Déruelle, B., Guiraud, R. and Vicat, J.-P. (2001) Magmatismes tholéiitique et alcalin des demi-grabens crétacés de Mayo Oulo-Léré et de Babouri-Figuil (Nord du Cameroun-Sud du Tchad) en domaine d'extension continentale. Comptes Rendus de 1 Académie des sciences, Paris, Sciences de la Terre et des planètes, 333, 201-207. https://doi.org/10.1016/S1251-8050(01)01626-3

[11] Abdelsalam, M.G., Liégeois, J.P. and Stern, R.J. (2002) Review the Saharan Metacraton. Journal of African Earth Sciences, 34, 119-136. https://doi.org/10.1016/S0899-5362(02)00013-1

[12] Ngako, V. and Njonfang, E. (2011) Plates Amalgamation and Plate Destruction, the Western Gondwana History. In: Closson, D., Ed., Plate, Intech, London, 1-36.

[13] Liégeois, J.P., Abdelsalam, M.G., Ennih, N. and Ouabadi, A. (2013) Metacraton: Nature, Genesis and Behavior. Gondwana Research, 23, 220-237.

https://doi.org/10.1016/j.gr.2012.02.016

[14] Toteu, S.F., Penaye, J. and Djomani, Y.H.P. (2004) Geodynamic Evolution of the Pan-African Belt in Central Africa with Special Reference to Cameroon. Canadian Journal of Earth Sciences, 41, 73-85. https://doi.org/10.1139/e03-079

[15] Toteu, S.F., Michard, A., Bertrand, J.M. and Rocci, G. (1987) U-Pb Dating of Precambrian Rocks from Northern Cameroon, Orogenic Evolution and Chronology of the Pan-African Belt of Central Africa. Precambrian Research, 37, 71-87. https://doi.org/10.1016/0301-9268(87)90040-4

[16] Toteu, S.F. (1990) Geochemical Characterization of the Main Petrographical and Structural Units of Northern Cameroon. Implication for Pan-African Evolution. 
Journal of African Earth Sciences, 10, 615-624.

https://doi.org/10.1016/0899-5362(90)90028-D

[17] Bouyo, M.H., Penaye, J., Njel, U.O., Moussango, A.P.I., Sep, J.P.N., Nyama, B.A., Wassouo, W.J., Abate, J.M.E., Yaya, F., Mahamat, A., Ye, H. and Wu, F. (2016) Geochronological, Geochemical and Mineralogical Constraints of Emplacement Depth of TTG Suite from the Sinassi Batholith in the Central African Fold Belt (CAFB) of Northern Cameroon: Implications for Tectonomagmatic Evolution. Journal of African Earth Sciences, 116, 9-41. https://doi.org/10.1016/j.jafrearsci.2015.12.005

[18] Toteu, S.F., Yongue Fouateu, R., Penaye, J., Tchakounté, J., Seme Mouangue, A.C., Van Schmus, W.R., Deloule, E. and Stendal, H. (2006) U-Pb Dating of Plutonic Rocks Involved in the Nappe Tectonic in Southern Cameroon: Consequence for the Pan-African Orogenic Evolution of the Central African Fold Belt. Journal of African Earth Sciences, 44, 479-493. https://doi.org/10.1016/j.jafrearsci.2005.11.015

[19] Pinna, P., Calvez, J.Y., Abessolo, A., Angel, J.M., Mekoulou, T., Mananga, G. and Vernhet, Y. (1994) Neoproterozoic Events in the Tcholliré Area: Panafrican Crustal Growth and Geodynamics in Central Northern Cameroon (Adamawa and North Provinces). Journal of African Earth Sciences, 18, 347-358. https://doi.org/10.1016/0899-5362(94)90074-4

[20] Pouclet, A., Vidal, M., Doumnang, J.C., Vicat, J.P. and Tchameni, R. (2006) Neoprotrozoic Crustal Evolution in Southern Chad: Pan-African Ocean Basin Closing. Are Accretion and Late to Postorogenic Granitic Intrusion. Journal of African Earth Sciences, 44, 543-560. https://doi.org/10.1016/j.jafrearsci.2005.11.019

[21] Penaye, J., Kröner, A., Toteu, S.F., Van Schmus, W.R. and Doumnang, J.C. (2006) Evolution of the Mayo-Kebbi Region as Revealed by Zircon Dating: An Early (ca. $740 \mathrm{Ma}$ ) Pan-African Magmatic Arc in Southwestern Chad. Journal of African Earth Sciences, 44, 530-542. https://doi.org/10.1016/j.jafrearsci.2005.11.018

[22] Kasser, M.-Y. (1995) Evolution précambrienne de la région du Mayo-Kebbi. Un segment de la Chaîne Panafricaine. Thèse Muséum National d'Histoire Naturelle de Paris. 217 p.

[23] Maurin, J.C. and Guiraud, R. (1990) Relationships between Tectonics and Sedimentation in the Barremo-Aptian Intracontinental Basins of Northern Cameroon. Journal of African Earth Sciences, 10, 331-340. https://doi.org/10.1016/0899-5362(90)90064-L

[24] Maurin, J.C. and Guiraud, R. (1993) Basement Control in the Development of the Early Cretaceous West and Central African Rift System. Tectonophysics, 228, 81-95. https://doi.org/10.1016/0040-1951(93)90215-6

[25] Isseini, M., André-Mayer, A.S., Vanderhaeghe, O., Barbey, P. and Deloule, E. (2012) A-Type Granites from the Pan-African Orogenic Belt in South-Western Chad Constrained Using Geochemistry, Sr-Nd Isotopes and U-Pb Geochronology. Lithos, 153, 39-52. https://doi.org/10.1016/j.lithos.2012.07.014

[26] Guiraud, R., Bellion, Y., Benkhelil, J. and Moreau, C. (1987) Post-Hercynian Tectonics in Northern and Western Africa. Geology Journal, 22, 433-466. https://doi.org/10.1002/gj.3350220628

[27] Guiraud, R. and Bosworth, W. (1997) Senonian Basin Inversion and Rejuvenation of Rifting in Africa and Arabia: Synthesis and Implications to Plate-Scale Tectonics. Tectonophysics, 282, 39-82. https://doi.org/10.1016/S0040-1951(97)00212-6

[28] Wilson, M. and Guiraud, R. (1998) Late Permian to Recent Magmatic Activity on the African-Arabian Margin of Tethys. In: Macgregor, D.S., Moody, R.T.J. and Clark-Lowes, D.D., Eds., Petroleum Geology of North Africa, Geological Society 
London Special Publications No. 132, 231-263.

https://doi.org/10.1144/GSL.SP.1998.132.01.14

[29] Guiraud, R. and Bellion, Y. (1995) Late Carboniferous to Recent Geodynamic Evolution of the West Gondwanian, Cratonic, Tethyan Margins. In: Nairn, A., Dercourt, J. and Vrielynck, B., Eds., The Ocean Basins and Margins, Vol. 8, The Tethys Ocean, Plenum, New York, 101-124. https://doi.org/10.1007/978-1-4899-1558-0_3

[30] Le Bas, M.J., Le Maitre, R.N., Streckeisen, A. and Zanettin, B. (1986) A Chemical Classification of Volcanic Rock Based on Total Silica Diagram. Journal of Petrology, 27, 745-750. https://doi.org/10.1093/petrology/27.3.745

[31] Irvine, T.N. and Baragar, W.R.A. (1971) A Guide to the Chemical Classification of the Common Volcanic Rocks. Canadian Journal of Earth Science, 8, 523-548. https://doi.org/10.1139/e71-055

[32] Floyd, P.A. and Winchester, J.A. (1975) Magma Type and Tectonic Setting Discrimination Using Immobile Elements. Earth and Planetary Science Letters, 27, 211-218. https://doi.org/10.1016/0012-821X(75)90031-X

[33] Sun, S.S. and McDonough, W.F. (1989) Chemical and Isotopic Systematics of Oceanic Basalts: Implications for Mantle Composition and Processes. Geological Society London Special Publications, 42, 313-345. https://doi.org/10.1144/GSL.SP.1989.042.01.19

[34] Cox, K.G. (1980) A Model for Flood Basalt Volcanism. Journal of Petrology, 21, 629-650. https://doi.org/10.1093/petrology/21.4.629

[35] Frey, F.A., Green, D.H. and Roy, S.D. (1978) Integrated Models of Basalt Petrogenesis: A Study of Quartz Tholeiites to Olivine Melilitites from South Eastern Australia Utilizing Geochemical and Experimental Petrological Data. Journal of Petrology, 19, 463-513. https://doi.org/10.1093/petrology/19.3.463

[36] Jung, S. and Masberg, P. (1998) Major- and Trace-Element Systematics and Isotope Geochemistry of Cenozoic Mafic Volcanic Rocks from the Vogelsberg (Central Germany): Constraints on the Origin of Continental Alkaline and Tholeiitic Basalts and Their Mantle Sources. Journal of Volcanology and Geothermal Research, 86, 151-177. https://doi.org/10.1016/S0377-0273(98)00087-0

[37] Xu, Y., Chung, S., Jahn, B. and Wu, G. (2001) Petrologic and Geochemical Constraints on the Petrogenesis of Permian-Triassic Emeishan Flood Basalts in Southwestern China. Lithos, 58, 145-168. https://doi.org/10.1016/S0024-4937(01)00055-X

[38] Eby, G.N. (1990) The A-Type Granitoids: A Review of Their Occurrence and Chemical Characteristics and Speculations on Their Petrogenesis. Lithos, 26, 115-134. https://doi.org/10.1016/0024-4937(90)90043-Z

[39] Chazot, G. and Bertrand, H. (1995) Genesis of Silicic Magmas during Tertiary Continental Rifting in Yemen. Lithos, 36, 69-83.

https://doi.org/10.1016/0024-4937(95)00012-5

[40] Sep Nlomngan, J.P., Penaye, J., Tchameni, R., Owona, S., Moussango Ibohn, A.P., Nsifa, E.N. and Toteu, S.F. (2019) Geochemical Characterization of Boula Ibi Granitoids and Implications in Geodynamic Evolution. Journal of Geography and Geology, 11, 13-28. https://doi.org/10.5539/jgg.v11n4p13

[41] Vaselli, O., Downes, H., Thirlwall, M.F., Vannucci, R. and Coradossi, N. (1996) Spinel-Peridotite Xenoliths from Kapfenstein (Graz Basin, Eastern Austria): A Geochemical and Petrological Study. Mineralogy and Petrology, 57, 23-50. https://doi.org/10.1007/BF01161620

[42] Stephen, A.N. (2006) Structure of the Earth and the Origin of Magmas. EENS, Tulane University. 
[43] Pearce, J.A. (1982) Trace Elements Characteristics of Lavas from Destructive Plate Boundaries. In: Thorpe, R.S., Ed., Andesite, J. Wiley and Sons, Chichester, 525-548.

[44] Dupuy, C. and Dostal, J. (1984) Trace Element Geochemistry of Some Continental Tholeiites. Earth and Planetary Science Letters, 67, 61-69. https://doi.org/10.1016/0012-821X(84)90038-4

[45] Marsh, J.S. (1989) Geochemical Constraints on Coupled Assimilation and Fractional Crystallization Involving Upper Crustal Compositions and Continental Tholeiitic Magma. Earth and Planetary Science Letters, 92, 70-80. https://doi.org/10.1016/0012-821X(89)90021-6

[46] Valbracht, P.J., Helmers, H. and Beunk, F.F. (1991) Early Proterozoic Continental Tholeiites from Western Bergslagen, Central Sweden, I. Petrology, Geochemical Petrogenesis and Geotectonic Setting. Precambrian Research, 52, 187-214. https://doi.org/10.1016/0301-9268(91)90080-T

[47] Tembo, F., Kampunzu, A.B. and Porada, H. (1999) Tholeiitic Magmatism Associated with Continental Rifting in the Lufilian Fold Belt of Zambia. Journal of African Earth Sciences, 28, 403-425. https://doi.org/10.1016/S0899-5362(99)00012-3

[48] Cadman, A.C., Tarney, J., Bridgewater, D., Mengel, F., Whitehouse, M.J. and Windley, B.F. (2001) The Petrogenesis of the Kangamiut Dyke Swarm, W. Greenland. Precambrian Research, 105, 183-203. https://doi.org/10.1016/S0301-9268(00)00111-X

[49] Srivastava, R.K. and Singh, R.K. (2004) Trace Element Geochemistry and Genesis of Precambrian Sub-Alkaline Mafic Dikes from the Central Indian Craton: Evidence for Mantle Metasomatism. Journal of Asian Earth Sciences, 23, 373-389. https://doi.org/10.1016/S1367-9120(03)00150-0

[50] Ingle, S., Scoates, J.S., Weis, D., Brugmann, G. and Kent, R.W. (2004) Origin of Cretaceous Continental Tholeiites in Southwestern Australia and Eastern India: Insights from Hf and Os Isotopes. Chemical Geology, 209, 83-106. https://doi.org/10.1016/j.chemgeo.2004.04.023

[51] Worthing, M.A. (2005) Petrology and Geochronology of a Neoproterozoic Dyke Swarm from Marbat, South Oman. Journal of African Earth Sciences, 41, 248-265. https://doi.org/10.1016/j.jafrearsci.2005.04.003

[52] Cox, K.G. and Hawkesworth, C.J. (1985) Geochemical Stratigraphy of the Deccan Traps at Mahabaleshwar, Western Ghats, India, with Implications for Open System Magmatic Processes. Journal of Petrology, 26, 355-377. https://doi.org/10.1093/petrology/26.2.355

[53] Leeman, W.P. and Hawkesworth, C.J. (1986) Open Magma Systems: Trace Element and Isotopic Constraints. Journal of Geophysical Research, 91, 5901-5912. https://doi.org/10.1029/JB091iB06p05901

[54] Zou, H., Zindler, A., Xu, X. and Qi, Q. (2000) Major, Trace Element, and Nd, Sr and $\mathrm{Pb}$ Isotope Studies of Cenozoic Basalts in SE China: Mantle Sources, Regional Variations, and Tectonic Significance. Chemical Geology, 171, 33-34. https://doi.org/10.1016/S0009-2541(00)00243-6

[55] Watt, G.R. and Harley, S.L. (1993) Accessory Phase Controls on the Geochemistry of Crustal Melts and Restites Produced during Water-Undersaturated Partial Melting. Contributions to Mineralogy and Petrology, 114, 550-566. https://doi.org/10.1007/BF00321759

[56] Beard, J.S., Lofgren, G.E., Sinha, A.K. and Tollo, R.P. (1994) Partial Melting of Apatite-Bearing Charnockite, Granulite, and Diorite: Melt Compositions, Restite Mineralogy, and Petrologic Implications. Journal of Geophysical Research Solid Earth, 99, 21591-21603. https://doi.org/10.1029/94JB02060 
[57] Ayres, M. and Harris, N. (1997) REE Fractionation and Nd-Isotope Disequilibrium during Crustal Anatexis: Constraints from Himalayan Leucogranites. Chemical Geology, 139, 249-269. https://doi.org/10.1016/S0009-2541(97)00038-7

[58] Wang, K., Plank, T., Walker, J.D. and Smith, E.I. (2002) A Mantle Melting Profile across the Basin and Range, SW USA. Journal of Geophysical Research, 107, 1-21. https://doi.org/10.1029/2001JB000209

[59] Jung, C., Jung, S., Hoffer, E. and Berndt, J. (2006) Petrogenesis of Tertiary Mafic Alkaline Magmas in the Hocheifel, Germany. Journal of Petrology, 47, 1637-1671. https://doi.org/10.1093/petrology/egl023

[60] Pearce, J.A. and Norry, M.J. (1979) Petrogenetic Implications of Ti, Zr, Y and Nb Variations in Volcanic Rocks. Contributions to Mineralogy and Petrology, 69, 33-47. https://doi.org/10.1007/BF00375192

[61] Meschede, M. (1986) A Method of Discriminating between Different Types of Mid-Ocean Ridge Basalts and Continental Tholeiites with the Nb-Zr-Y Diagram. Chemical Geology, 56, 207-218. https://doi.org/10.1016/0009-2541(86)90004-5

[62] Tchouankoué, J.P., Simeni Wambo, A.N., Kagou Dongmo, A. and Wörner, G. (2012) Petrology, Geochemistry, and Geodynamic Implications of Basaltic Dyke Swarms from the Southern Continental Part of the Cameroon Volcanic Line, Central Africa. The Open Geology Journal, 6, 72-84. https://doi.org/10.2174/1874262901206010072

[63] Vicat, J.P., Ngounouno, I. and Pouclet, A. (2001) Existence de dykes doléritiques anciens à composition de tholéiites continentales au sein de la province alcaline de la Ligne du Cameroun. Implication sur le Contexte géodynamique. Comptes Rendus de P Académie des Sciences, Paris, IIA, 332, 243-249. https://doi.org/10.1016/S1251-8050(01)01526-9

[64] Njel, U.O. (1986) Paléogéographie d'un segment de l'orogenèse panafricaine: La ceinture volcano-sédimentaire de Poli (Nord Cameroun). Comptes Rendus de IAcadémie des Sciences, Paris, 303, 1737-1742.

[65] Bouyo Houketchang, M., Toteu, S.F., Deloule, E., Penaye, J. and Van Schmus, W.R. (2009) U-Pb and Sm-Nd Dating of High-Pressure Granulites from Tchollire and Banyo Regions: Evidence for a Pan-African Granulite Facies Metamorphism in North-Central Cameroon. Journal of African Earth Sciences, 54, 144-154. https://doi.org/10.1016/j.jafrearsci.2009.03.013

[66] Doumnang, J.-C. (2006) Géologie des formations néoprotérozoïques du Mayo Kebbi (sud-ouest du Tchad): Apports de la pétrologie et de la géochimie, implications sur la géodynamique au Panafricain. Université d'Orleans, Thèse de Doctorat, 223.

[67] Toteu, S.F., Van Schmus, R.W., Penaye, J. and Michard, A. (2001) New U-Pb and Sm-Nd Data from North-Central Cameroon and Its Bearing on the Pre-Pan-African History of Central Africa. Precambrian Research, 108, 45-73.

https://doi.org/10.1016/S0301-9268(00)00149-2 